NBER WORKING PAPER SERIES

\title{
LABOR SUPPLY OF POLITICIANS
}

\author{
Raymond Fisman \\ Nikolaj A. Harmon \\ Emir Kamenica \\ Inger Munk \\ Working Paper 17726 \\ http://www.nber.org/papers/w17726
}

\author{
NATIONAL BUREAU OF ECONOMIC RESEARCH \\ 1050 Massachusetts Avenue \\ Cambridge, MA 02138 \\ January 2012
}

This work is supported by the William Ladany Faculty Research Fund at the University of Chicago Booth School of Business and the Center for International Business Education and Research at Columbia University. The views expressed herein are those of the authors and do not necessarily reflect the views of the National Bureau of Economic Research.

NBER working papers are circulated for discussion and comment purposes. They have not been peerreviewed or been subject to the review by the NBER Board of Directors that accompanies official NBER publications.

(C) 2012 by Raymond Fisman, Nikolaj A. Harmon, Emir Kamenica, and Inger Munk. All rights reserved. Short sections of text, not to exceed two paragraphs, may be quoted without explicit permission provided that full credit, including $(\odot)$ notice, is given to the source. 
Labor Supply of Politicians

Raymond Fisman, Nikolaj A. Harmon, Emir Kamenica, and Inger Munk

NBER Working Paper No. 17726

January 2012

JEL No. D72,D73

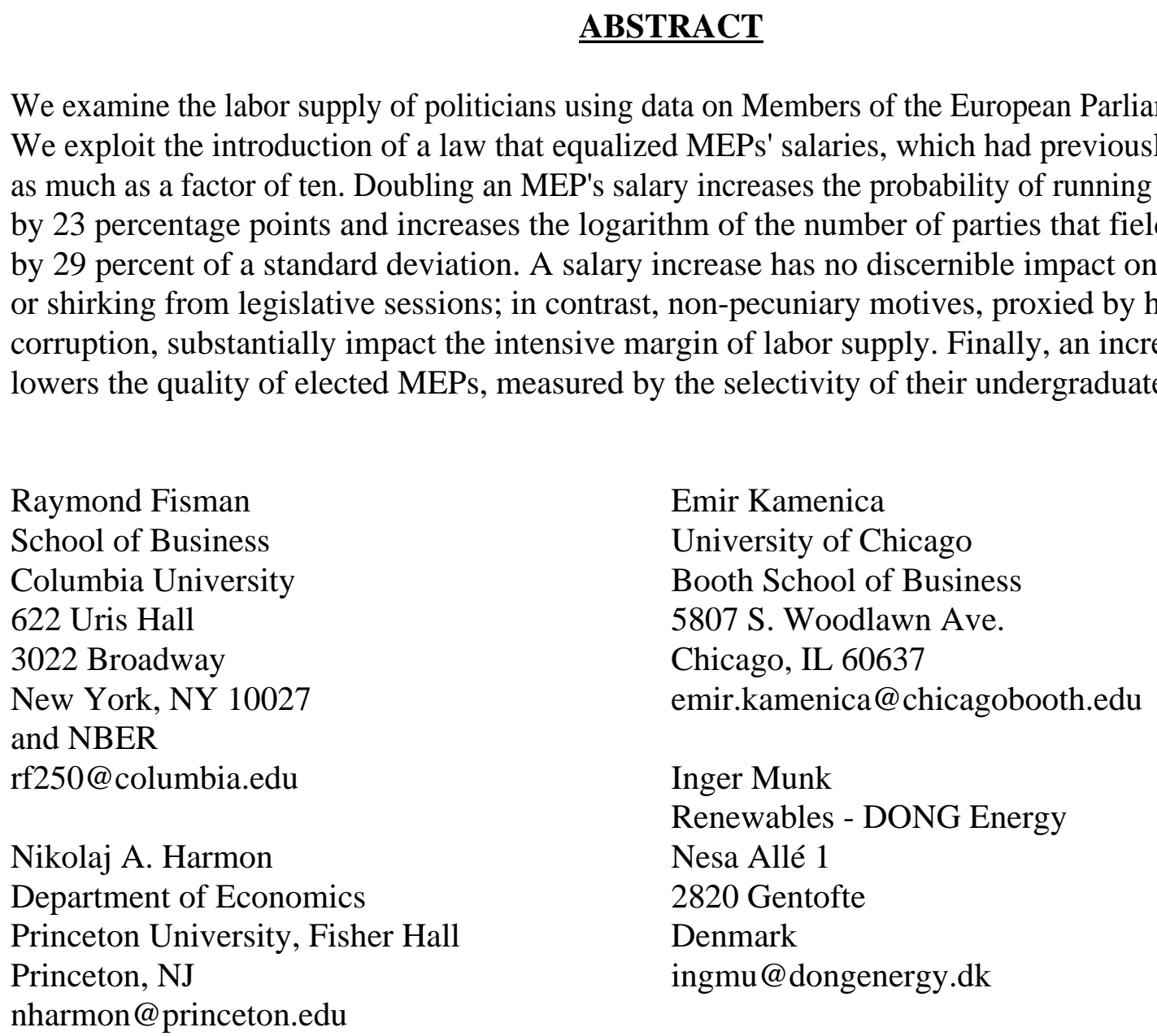




\section{Introduction}

The labor market for politicians is unlike that of most occupations: salaries are determined through legislation rather than market forces and politicians vie for a fixed number of positions through public competition, facing the possibility of dismissal only once each electoral cycle. Since politicians' salaries are a policy variable, it is particularly important to identify the role that financial compensation plays in their labor supply. Moreover, given the visible nature of their duties, the lack of direct supervision, and the public goods aspect of their jobs, it is also critical to understand how social norms affect politicians' behavior while they are in office.

In this paper, we analyze the impact of both salary and social norms on the labor supply of the Members of the European Parliament (MEPs). We examine three aspects of politicians' labor supply: (i) the extensive margin (the willingness to run for office), (ii) the intensive margin (effort exerted while in office), and (iii) selection effects (quality of elected candidates).

Our main source of identification is a recent change in the way that MEP salaries are determined. The European Parliament is the directly elected legislative chamber of the European Union. It is currently composed of 736 MEPs from 27 constituent countries. MEPs are elected for 5-year terms by voters from their home countries. Prior to 2009, each MEP received the same salary as the members of the lower house of her home-country national parliament. This induced great variation in MEPs' remuneration. For example, in 2004, the highest paid MEPs (those from Italy) were paid an annual salary of $€ 144,084$ while the lowest paid ones (those from Hungary) earned €10,080 per year. Even MEPs from similar countries received very different salaries. For example, Spanish MEPs were paid €38,396 per year, roughly $75 \%$ less than Italian MEPs, despite the countries' nearidentical levels of GDP per capita. In 2005, the two legislative chambers of the European Union agreed on a salary harmonization: as of the first day of the parliamentary term starting in 2009, almost $^{1}$ all MEPs receive an identical salary of roughly $€ 84,000$. For some MEPs (e.g., those from Italy) this change induced a large reduction in salary, while for others (e.g., those from Hungary and Spain), it meant a big raise. At the same time, MEPs are drawn from a heterogeneous mix of nations, which allows us to examine the supply of politicians as a function not only of income, but

\footnotetext{
${ }^{1}$ As we will explain in greater detail later, there is a small fraction (4.5\%) of MEPs for whom this salary change did not apply.
} 
of home-country norms as well. We can thus compare the effects of pecuniary and non-pecuniary motivations of politicians.

We measure the extensive margin of labor supply in three ways. First, we examine whether incumbent MEPs seek reelection. Second, we look at whether MEPs quit before completing their terms of office. Third, we identify the number of parties that field a candidate. ${ }^{2}$ We generate two primary measures of the intensive margin of labor supply: the rate of absences from plenary sessions, and a more direct proxy for shirking based on instances when an MEP signs the attendance register (thus collecting a daily stipend) but fails to cast a single vote. Finally, we examine quality of elected MEPs, as proxied by the selectivity of their undergraduate institutions.

Doubling an MEP's salary increases the probability she runs for reelection by 23 percentage points and increases the logarithm of the number of parties that field a candidate by 29 percent of a standard deviation. Moreover, an increase in salary substantially reduces the likelihood that an MEP will quit before the end of her term. All of these results suggest that monetary remuneration plays an important role in the willingness to hold political office. One one hand, these results may not be surprising - higher salaries attract more applicants in other industries, so why should this not be the case in politics? But, as we note at the outset, politicians' labor supply may be governed by distinct forces. Both non-pecuniary motivations and the role of post-political employment are such that salary might be of secondary importance relative to other returns to holding office (see Diermeier et al. 2005, who argue that this is the case in the U.S. Congress). ${ }^{3}$

We do not find evidence that an increase in salary impacts the intensive margin of labor supply.

In contrast, we find a strong effect of non-pecuniary factors on whether MEPs exert effort while they are in office. We use cross-sectional variation in corruption as a proxy for the strength of home-country social capital and find that MEPs from more corrupt countries are more likely to be absent from all votes on a given day. As well as indulging in more absences, MEPs from more corrupt countries also exhibit a more explicit form of shirking. Each day they are present at the

\footnotetext{
${ }^{2}$ Many countries in the European Union use closed-list voting systems where citizens cast votes for parties rather than individual candidates. Consequently, we are not able to identify the number of individual candidates willing to run for office in each country.

${ }^{3}$ In interpreting our estimates, it is important to note that the elasticity of labor supply will in general depend on the existence of substitute career options, and in our context, there is a political position that may be a reasonably close substitute to being an MEP, namely serving in the home-country parliament. Consequently, the impact of salary on the supply of political candidates may be somewhat lower in other settings.
} 
parliament, MEPs are meant to sign a register to prove their attendance, entitling them to a daily allowance of roughly $€ 300 .{ }^{4}$ MEPs have sometimes abused this system, showing up only to sign the register. Such behavior has been a source of scandal. In 2004, for example, Austrian MEP Hans-Peter Martin filmed other MEPs signing the register shortly after 7am and then immediately leaving the building. His footage was widely broadcast and caused a public uproar. ${ }^{5}$ Combining data from the daily register with roll-call voting data, we identify for each MEP any days on which she signed the register but was then absent from all votes that day. We find that a one standard deviation increase in corruption in an MEP's place of origin is associated with a 16 percent increase in this form of shirking.

Finally, we examine the impact of the salary change on the composition of elected officials. Doubling the salary decreases the probability that an elected MEP attended a college ranked among the top 500 in the world by 4.2 percentage points, or 14 percent. ${ }^{6}$ Moreover, a salary increase seems to attract MEPs who shirk more, but this effect is not robust to inclusion of country fixed effects. Overall, our evidence suggests that higher salaries lower the quality of elected MEPs.

The identifying assumption underlying our results on pecuniary motivations is that the timing of the salary reform is uncorrelated with other factors that would lead politicians from low-salary countries to increase their willingness to be MEPs relative to politicians from from high-salary countries. Another concern is that the reform may have been passed precisely when MEPs from low-salary countries were more likely to run for reelection and thus were particularly motivated to raise future salaries. Two sets of facts speak against this alternative explanation. First, such reverse causality could not account for the increase in the number of parties that field candidates when salaries increase. Second, we demonstrate that whether an MEP voted for or against salary harmonization is uncorrelated with whether the proposal would raise or lower her salary. ${ }^{7}$

A large literature examines the theoretical relationship between politicians' wages, and their quality, performance, and willingness to run for office. Caselli and Morelli (2004) consider a setting

\footnotetext{
${ }^{4}$ The size of the daily allowance changes somewhat over time.

${ }^{5}$ See, for example, "European Elections: Martin's Travels," The Economist, June 3, 2004.

${ }^{6}$ College selectivity is highly predictive of market productivity (Kane 1998). It is not immediately clear, however, whether it is also a good proxy for the quality of a politician. That said, we find that, conditional on running, selectivity of an MEP's college strongly predicts whether she will win a reelection. This patterns support our view that college selectivity is a good proxy for MEPs' quality.

${ }^{7}$ Moreover, whether an MEP voted for or against salary harmonization is uncorrelated with whether that MEP subsequently runs for reelection.
} 
where market and political ability are correlated, so higher wages attract candidates with greater political skill. Besley (2004) develops a model where higher wages compel politicians to care more about reelection; an increase in wages thus induces politicians to cater more to voters' preferences while in office. Higher wages, however, might also create negative selection effects, as our results suggest to be the case. New Hampshire has deliberately kept legislators' salaries at $\$ 100$ for their 45 days in session each year (with no per diem), reasoning that this system attracts a more committed "citizen" legislature. Directly in line with this rhetoric, Besley (2004) discusses how the existence of non-pecuniary incentives for "public spirited" candidates might cause higher wages to attract less attractive candidates. Poutvaara and Takalo (2007), Mattozzi and Merlo (2008), and Gagliarducci, Nannicini, and Naticchioni (2010) consider models where high-ability people self-select into politics; consequently, higher wages lower the ability threshold at which potential candidates decide to seek office. $^{8}$

In contrast to theoretical work, there is a relative paucity of empirical research on the labor market for elected officials, owing in large part to the difficulty in credibly identifying a relationship between pay and the supply of politicians. Outside of politics, one can often use exogenous shocks to labor demand to identify the elasticity of labor supply, but this approach is not feasible in studying the labor supply of politicians. Moreover, since salaries are typically set by those currently in office, it is usually difficult to rule out the possibility that politicians' skill affects their salaries rather than vice versa. A pair of recent papers overcome these difficulties by exploiting discontinuities of politicians' salaries in population size: Ferraz and Finan (2010) and Gagliarducci and Nannicini (forthcoming) examine the impact of wages on labor supply and performance of Brazilian municipal legislators and Italian mayors, respectively, and find that higher wages attract more candidates and higher quality candidates in both contexts. Ferraz and Finan (2010) also find evidence that higher wages induce higher effort, while Gagliarducci and Nannicini (forthcoming) find this channel to be unimportant. Kotakorpi and Poutvaara (2011) study the effect of a wage increase in the Finnish National Parliament. Using candidates in municipal elections as a control group, they report that the wage increase led to more educated female candidates but had no effect on the composition

\footnotetext{
${ }^{8}$ Messner and Polborn (2004) study a model where candidates are motivated to run in part because they care about political duties being executed effectively. In this setting, higher wages can decrease the quality of elected officials since higher wages allow skilled individuals to more easily free-ride on participation of others.
} 
of male candidates. Di Tella and Fisman (2004) present evidence that better state-level economic performance allows U.S. governors to push up their own salaries, while Besley (2004) finds that U.S. governors' salaries increase when their policies are congruent with voter preferences. Groseclose and Krehbiel (1994) and Hall and van Houweling (1995) report that U.S. congressmen respond to changes in the financial incentives for retirement. The structural estimation exercise of Keane and Merlo (2010) suggests that a reduction in congressional salaries in the U.S. would disproportionally induce exit of skilled politicians.

Closest to the context we explore in our paper is the concurrent work by Mocan and Altindag (2011). They also study the impact of the change in European Parliament salary rules on the behavior of MEPs. However, they examine the impact of the salary change only on whether MEPs sign the daily register, while we focus on a broader set of outcomes (the willingness to run for reelection, quality of MEPs, number of parties that field a candidate, absence from roll-call votes, and so forth). Moreover, in contrast to their findings, we do not find that the salary change has a significant impact on the tendency to sign the daily register. We replicate their point estimate, which is quite small, and when we cluster our standard errors at the country level, ${ }^{9}$ the effect is not statistically significant.

Our paper contributes to the existing literature by providing a more complete view of politicians' labor supply - in our setting, we can examine the impact of both pecuniary and non-pecuniary factors, measure both the extensive and the intensive margin of labor supply, and also identify selection effects. Furthermore, in contrast to most earlier work, the European Parliament wage equalization provides us with a credible source of identification of the impact of salary changes. Finally, some of the outcomes we analyze, such as the supply of political parties, have not been studied at all in previous work.

The remainder of the paper is structured as follows. In the next section we describe the data and the institutional background. Section 3 presents the results. The last section concludes.

\footnotetext{
${ }^{9}$ Mocan and Altindag (2011) cluster their standard errors at the MEP level.
} 


\section{Data and institutional background}

The European Parliament is the lower legislative chamber of the European Union. Since 1979, Members of the European Parliament (MEPs) have been elected every 5 years. The present paper focuses on the 5th, 6th, and 7th parliaments, elected in 1999, 2004, and 2009 and consisting of 626, 732, and 736 MEPs, respectively. ${ }^{10}$ Throughout the paper, we will refer to the $n^{\text {th }}$ parliament as $E P n$.

Each EU member country elects its own MEPs in nationally held elections. The precise electoral rules differ by country. Importantly for our purposes, many countries utilize closed-list electoral systems where voters can effectively vote only for political parties as a whole, rather than for particular candidates. In such countries, competition takes place at the party-level rather than at the individual-level. Consequently, when we analyze the extensive margin of labor supply, we focus on incumbents' willingness to run for reelection and the number of parties that field at least one candidate. $^{11}$

The work of the European Parliament is centered around the plenary sessions held once or twice a month. These sessions consist of several daily "sittings" of debate and voting. MEPs sign attendance registers on each day of a plenary session. The registers are subsequently published in conjunction with the minutes of the sittings. Similarly, for those votes that are held as roll-call votes, individual voting is registered and published.

MEPs are remunerated through allowances as well as a monthly salary. Along with reimbursement for travel, staff, and other expenses, MEP allowances include a stipend that is awarded for each day of a session, if the MEP signs the attendance register. This daily stipend is reduced by a half if the MEP votes on fewer than 50 percent of the roll-call votes that day. Signing the register and then immediately leaving is frowned upon, as evidenced by the scandal discussed in the introduction.

Prior to EP7, MEPs were paid by the member states and earned the same salary as members of the lower chamber of their respective national parliaments. This system was originally put in

\footnotetext{
${ }^{10}$ When Romania and Bulgaria joined the EU in 2007, the total number of MEPs temporarily increased to 785 until the 2009 election.

${ }^{11}$ An alternative would be to restrict our attention to countries with open-list electoral systems and utilize the overall number of candidates on the ballot. There are only nine such countries in EP7 (Hix and Hagemann 2009), however, which is insufficient for this approach.
} 
place in 1979 as a placeholder until the European Parliament could decide on a uniform system and level of salaries. Difficulties in agreeing to a uniform salary and its implementation, however, resulted in the national parliament salaries remaining in place for nearly three decades. A new system was finally agreed and voted upon on June 23, 2005 and became effective in EP7. The new system established a uniform salary for all MEPs, paid from the European budget and equal to $38.5 \%$ of the salary of a judge at the European Court of Justice. The statute was passed with two provisos: (i) if any member state wished all of its MEPs to continue to receive the old, national salary, this would be permitted for a maximum of two parliamentary terms and would be paid for by the member state, and (ii) any individual MEP who was already in office before the new statute was passed could elect to continue to receive the old, national salary (paid by her own member state) for as long as she continued in office. In practice, these provisions had little impact on the implementation of a uniform salary because: (i) no member state elected to continue to pay the old salaries for its MEPs, and (ii) only 33 MEPs exercised the option to retain the old national salaries. ${ }^{12}$ We have been able to identify only 5 of these 33 MEPs, so we cannot exclude all MEPs with unchanged salaries from our analyses. That said, they comprise less than 5 percent of the sample, so their effect on our estimates is likely to be small. Moreover, since their salaries did not actually change, they are likely to bias our estimates toward zero.

The data employed in this paper are derived from a number of sources. We obtained data on salaries from Corbett, Jacobs, and Shackleton (2005). We use the salaries as of December of 2004 as the measure of the salary level in the 6th parliament (2004-2008). Our key independent variable $\Delta \operatorname{lnSalary}_{c}$ is defined as the logarithm of 84,000 (the post-change uniform salary level) minus the $\operatorname{logarithm}$ of the salary for MEPs from country $c$ as of December of $2004 .^{13}$

The measures of the extensive margin of labor supply are constructed using data available on the web pages of the European Parliament. ${ }^{14}$ For EP6 and EP7, for each MEP who served in the

\footnotetext{
${ }^{12}$ At first glance it might seem surprising that MEPs who received a pay cut would not elect to keep their old salaries. Doing so, however, would require transferring the burden of payment from the European Parliament to the taxpayers of one's own country, which might not be popular with the electorate. More broadly, many legislative bodies have the legal power to raise their own salaries and yet seldom choose to do so.

${ }^{13}$ We also considered the tax-adjusted salary change, using the top marginal tax rate in the home country. Since the tax rates are uncorrelated with initial salaries, this alternative measure yields very similar results.

${ }^{14}$ Data on whether incumbent MEPs ran for reelection in 2004 was taken in July 2009 from http://www.europarl.europa.eu/parliament/archive/staticDisplay.do?language=EN\&id=75. Information on whether MEPs ran for reelection in 2009 was downloaded during the election in June 2009. Data on when MEPs left the parliament was collected in August 2009 from the individual MEP pages on the EP website,
} 
previous parliament, we define a variable $R_{e} R_{u n}$ ip that indicates whether she ran for reelection $(i$ indexes the MEP and $p$ indexes the parliament). ${ }^{15}$ For EP5 and EP6, for each MEP who served in that parliament, we define an indicator variable PostVoteQuit $t_{i p}$ which equals 1 if MEP $i$ quit her job before completing her term at some point after June 23rd of the second calendar year of parliament $p$. For $p=6$, this indicates that the MEP quit the parliament at some point after the vote on the salary change. For $p=5$, this indicates she quit the parliament during the same segment of the electoral cycle but in the parliamentary session prior to the introduction of salary change legislation. Finally, for EP6 and EP7, for each member country, we collected data on the number of parties that fielded a candidate, taken from the European Parliament's website. ${ }^{16}$ The available data only include parties that received at least $0.5 \%$ of the vote. Accordingly, we define $\operatorname{lnNumParties} s_{c p}$ as the logarithm of the number of parties in country $c$ that received at least $0.5 \%$ of the vote for candidacy to parliament $p$. These three variables, ReRun $i p$, PostVoteQuit ${ }_{i p}$, and $\ln N u m$ Parties $_{c p}$, will be our measures of the extensive margin of labor supply.

Building on a previous data collection effort by Hix, Noury, and Roland (2007), we also put together comprehensive data on attendance and roll-call voting in the daily sittings of EP5, EP6, and the first year of EP7. ${ }^{17}$ As mentioned previously, a sitting is a day-long meeting of the parliament during which roll-call voting takes place. For each sitting, our data contain information about whether each serving MEP signed the attendance register and how she voted (if at all) on the issues that day. ${ }^{18}$ We focus on attendance and voting records during the first year of each parliament, to avoid comparing behaviors across different points in the electoral cycle and further to concentrate on behavior during the period of EP6 that occurred before the salary vote.

Variable Fraction Absent ${ }_{i p}$ captures the fraction of sittings in parliamentary session $p$ during

http://www.europarl.europa.eu/members/archive/alphaOrder.do?language=EN.

${ }^{15}$ These data are missing for 16 observations.

${ }^{16}$ http://www.europarl.europa.eu/parliament/archive/elections2009/en/new_parliament_en.html and http://www.europarl.europa.eu/parliament/archive/elections2009/en/hist_results_be_en.html accessed in July 2009.

${ }^{17}$ Data on voting and attendance in the plenaries of EP6 and EP7 was collected from the published daily minutes on the European Parliament website, http://www.europarl.europa.eu/activities/plenary/home.do?language=EN, between February 2007 and October 2010. We also collected data on attendance in EP5 which we combined with voting information from the Hix, Noury, and Roland (2007) data (downloaded in November 2007).

${ }^{18}$ The published minutes of the meetings also contain information on so-called vote corrections where an MEP asks to have her registered vote changed in the minutes (without affecting the actual outcome). In our empirical work we focus on the pre-correction voting outcome but results are robust to considering corrected votes instead. There are also some instances of secret ballot votes in the data, where each MEP's vote is not made public. For these it is still recorded whether each MEP voted. 
which MEP $i$ did not participate in any of the votes during the day. (An abstention counts as a vote.) Variable FractionSignedIn $n_{i p}$ reflects the fraction of sittings in parliament $p$ during which MEP $i$ signed the daily register. This outcome measure is difficult to interpret since it conflates effort (showing up to work) and greed (signing the register even if you are not going to work), and we use it primarily to compare our results to existing findings in the literature. Finally, motivated by the scandals mentioned in the introduction, variable FractionSignedInAbsent $t_{i p}$ is defined as the fraction of those sittings in year $t$ when MEP $i$ signed the register but cast zero votes. There are legitimate reasons an MEP might sign the register but fail to participate in votes - for example, she might spend the entire day in meetings. That said, we are primarily interested in salary and corruption as predictors of FractionSignedInAbsent ${ }_{i p}$, and there are no obvious reasons why these variables would be correlated with such alternative uses of an MEP's time. Moreover, if we focus on days when the parliament voted on more contentious issues - those that passed or failed by a margin smaller than 10 votes - we obtain very similar results. Variables FractionAbsent ${ }_{i p}$, FractionSignedIn $_{i p}$, and FractionSignedInAbsent $i p$ are our measures of the intensive margin of labor supply.

We are also interested in the impact of salary change on the selection of politicians. We use global rankings of colleges attended by MEPs as a measure of MEP quality. From MEPs' individual websites, we identified where each attended college. We were able to obtain this information for nearly 90 percent of the sample. We merged these data with the 2010 Academic Ranking of World Universities, which provides a rank for the top 500 universities in the world. ${ }^{19}$ The variable FractionRankedCollege $_{c p}$ is the fraction of MEPs from country $c$ in parliament $p$ who attended a school ranked in the top 500. ${ }^{20}$ Most MEPs attend college in their home country, and countries vary widely in their universities' representation in the ranking. Consequently, FractionRankedCollege $e_{c p}$ is not particularly useful for identifying cross-sectional variation in the quality of MEPs across countries, but it does capture the change in quality of MEPs from a given country over time. We could have also defined similar variables with a different cutoff, e.g., a fraction of MEPs who

\footnotetext{
${ }^{19}$ Since rankings might change somewhat over time, it would have been more suitable to utilize the rank of a school at the time when the MEP attended it, but the available data only go back to 2003 and many MEPs have been out of college for more than seven years.

${ }^{20}$ For our main specification, we simply drop the 10 percent of MEPs without education data and treat the information as missing randomly. Including all MEPs in the analysis and coding those with missing data as having gone to an unranked school strengthens our results.
} 
attended a school ranked in the top 200, but since only about 29 percent of MEPs with available education data attended a ranked school at all, FractionRankedCollege $e_{c p}$ captures most of the relevant variation.

MEPs' individual websites provided us with data on each MEP's age and periods in office, on the basis of which we define self-explanatory variables $A g e_{i p}, A g e S q_{i p}$, and $\operatorname{lnTenure}{ }_{i p}$, which reflect age and tenure the first year of parliament $p$. We gathered country-by-year data on GDP per capita in constant 2000 U.S. dollars, and control for income at the beginning of each parliament $\left(\ln G D P P C_{c p}\right)$ from the World Development Indicators. Finally, as our measure of corruption (Corruption $_{c p}$ ) we use data from Kaufmann, Kraay, and Mastruzzi (2010). These data consist of a composite corruption index that is essentially the first principal component of a number of other commonly used corruption indices, which are usually subjective measures based on surveys of country experts and investors. For ease of interpretation, we reverse the sign of the original measure so that higher values indicate greater corruption, and assign a value to each EP-country

observation based on the corruption index in the first year of the parliament. By construction, the mean value of this measure across all countries in the global sample is zero with standard deviation one; for our sample of European countries it ranges from -2.2 to -0.3. Table 1 reports summary statistics for the variables used in our analysis.

\section{Impact of salary and social norms on labor supply and selection of MEPs}

As we mentioned earlier, in the past MEPs received the same salary as members of the lower house of their own national parliament. Table 2 reports MEPs' salaries by country as of December 2004, during the 6th parliament. Starting with EP7, which began in July 2009, salaries were equalized to roughly $€ 84,000$ for all MEPs. Our empirical strategy for estimating the impact of salary change on labor supply is based on the assumption that the timing of this salary change is uncorrelated with a change in omitted variables that would differentially influence the labor supply of MEPs from countries that initially had low and high salaries.

To identify the impact of social capital on labor supply, we rely on the cross-sectional variation 
in corruption across countries. We take a broad interpretation of this country-level measure as reflecting values of public service over private gain.

\subsection{Extensive margin of labor supply}

Our first specification examines the impact of the salary change on the willingness of incumbent MEPs to seek reelection. We consider a linear probability model: ${ }^{21}$

$$
\operatorname{ReRun}_{i p}=\beta_{0}+\beta_{1} \times \Delta \text { lnSalary }_{c}+\beta_{2} \times E P 7_{p}+\beta_{3} \times E P 7_{p} \times \Delta \operatorname{lnSalary}_{c}+\varepsilon_{i p}
$$

where $p \in\{6,7\}$. The sample consists of all MEPs who served in EP5, and those MEPs who served in EP6 and joined the parliament prior to the announcement of the salary change. ${ }^{22} E P 7_{p}$ is an indicator variable for whether $p=7$. ReRun $i p$ denotes whether MEP $i$ ran for reelection for parliament $p$, and $\Delta$ lnSalary $_{c}$ is the salary change instituted at the beginning of EP7, defined in the previous section. In this specification, as in all others, robust standard errors are clustered by country.

Coefficient $\beta_{1}$ captures the cross-sectional relationship between the salary in EP6 and the willingness of MEPs who served in EP5 to run for reelection for EP6. Since $\Delta \ln S a l a r y_{c}$ is defined as a constant $(\ln (84000))$ minus log of salary in EP6, a negative $\beta_{1}$ indicates a positive crosssectional relationship between salary and the extensive margin of labor supply. Coefficient $\beta_{2}$ tells us whether, in the absence of a salary change, MEPs are overall more likely to run for reelection for EP7 or for EP6. The main coefficient of interest is $\beta_{3}$, which identifies the impact of the salary change on willingness to run for reelection.

Column (1) of Table 3 reports the results without controls. The estimate of $\beta_{1}$ is -0.18 $(p<0.01)$ suggesting that MEPs from high-salary countries were more likely to run for reelection for EP6. Note, however, that all of the MEPs in the sample had already expressed their willingness to hold the office at the salary level offered by their country. Consequently, $\hat{\beta}_{1}$ should be interpreted with caution. The estimate of $\beta_{2}$ is $-0.090(p<0.01)$ which means that, in the absence of a salary change, MEPs were about 9 percentage points less likely to run for reelection for EP7 than for EP6.

\footnotetext{
${ }^{21}$ Throughout the paper we use a linear probability model when the outcome variable is binary. We obtain very similar results if we use logit or probit specifications instead.

${ }^{22}$ This means that we exclude all MEPs from Romania and Bulgaria since they joined in 2007.
} 
The estimate of $\beta_{3}$ is $0.30(p<0.01)$. This implies that doubling an MEP's salary (a magnitude of change well within the range of salary changes observed in the data) increases the likelihood that the MEP runs for reelection by 21 percentage points $\left(\ln (2) \times \hat{\beta}_{3}=0.21\right)$. Given that on average 57 percent of MEPs seek reelection (Table 1), this constitutes a 37 percent increase in labor supply. This magnitude is sufficiently large for $\hat{\beta}_{1}+\hat{\beta}_{3}=0.13$ to be significantly higher than zero $(p<0.01)$. This means that, even though all MEPs receive the same salary in EP7, those MEPs who had previously received a higher salary in EP6 are less willing to run for office in EP7. This could be caused either by selection (MEPs from higher salary countries have a higher reservation wage), or by preferences that depend on salary changes as well as salary levels (Kahneman and Tversky 1979).

Countries in the European Union utilize three different types of voting systems. In open-list systems, voters cast votes for particular candidates (most of whom are identified with a party). In closed-list systems, voters vote for parties, each of which maintains a list of candidates. Finally, in ordered-list systems, voters can either vote for a party or for an individual on a party list, but a high proportion of votes is required to undo the party-mandated ordering of candidates. The process of seeking reelection thus differs as a function of the electoral system employed: in an openlist system, a candidate directly chooses to run while in a closed-list system she needs her party's approval to do so. In Figure 1, we plot the change in the fraction of MEPs who run for reelection

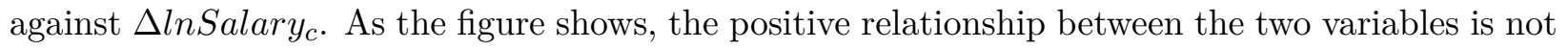
driven by extreme observations, nor by countries with a particular electoral system.

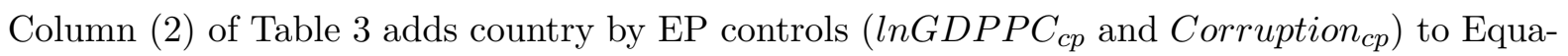
tion 1. These variables are measured in the last year of parliament $p-1$, i.e., at the time when the MEP was likely making the decision of whether to run for reelection. Column (3) adds MEP by EP controls $\left(A g e_{i p}, A g e S q_{i p}\right.$, and $\left.\operatorname{lnTenure}{ }_{i p}\right)$, also measured in the last year of parliament $p-1$. Column (4) adds country fixed effects. The estimate of our key coefficient of interest, $\beta_{3}$, is stable across these four specifications. ${ }^{23}$ The estimate in column (4), which contains our preferred specification, implies that a doubling of MEP salary increases the likelihood of rerunning by 23

\footnotetext{
${ }^{23}$ We also ran a specification that included the 2007-2009 change in $\ln G D P P C_{c p}$ interacted with $E P 7$ as a control, to account for possible effects of the financial crisis on the decision to run for reelection. This had no effect on the coefficients of interest in Table 3, or those in Table 4 below.
} 
percentage points.

A somewhat stronger way to express diminished interest in serving as an MEP is to quit before the term expires. In Table 4, we consider a linear probability model:

$$
\text { PostVoteQuit }_{i p}=\beta_{0}+\beta_{1} \times \Delta \text { lnSalary }_{c}+\beta_{2} \times E P 6_{p}+\beta_{3} \times E P 6_{p} \times \Delta \operatorname{lnSalary} c+\varepsilon_{i p}
$$

where $p \in\{5,6\}$ and $E P 6_{p}$ is an indicator variable for whether $p=6$. Recall that PostVoteQuit $t_{i p}$ equals 1 if MEP $i$ quit her job before completing her term at some point after June 23rd of the second calendar year of parliament $p$. For $p=6$, this indicates quitting the parliament after the vote on the salary change. For $p=5$, this indicates quitting the parliament during the same segment of the electoral cycle, but in the parliamentary session before the salary change had been introduced. As in Table 3, Column (1) reports the baseline results, Column (2) adds country by EP controls, Column (3) adds MEP by EP controls, and Column (4) adds country fixed effects. The estimate of our key coefficient of interest, $\beta_{3}$, changes somewhat across the specifications, but it is always negative and is statistically significant when we include MEP by EP controls and/or country fixed effects, our preferred specifications. Overall, the results in Table 4 suggest that a lower salary increases the likelihood that an MEP will quit her job before completing her term of office.

The results in Tables 3 and 4 focus on the willingness of incumbent politicians to continue to hold their offices. More directly relevant for the welfare of the electorate is the overall supply of potential candidates and platforms. It is not feasible to identify the overall number of potential candidates, however, because only nine member countries have open-list electoral systems. We therefore focus on the number of political parties that field candidates. This measure applies equally well to countries that use closed-list and open-list electoral systems, since even in countries with open-list systems almost all candidates are associated with some political party. ${ }^{24}$ In Table 5 ,

\footnotetext{
${ }^{24}$ Readers familiar primarily with the political system of the United States should note that most European countries have a large number of politically active parties and some of those parties are at the margin where they might focus exclusively on national politics or might spend some of their resources vying for a greater role in European politics. At the same time, in many countries small parties focusing only on European politics (and oftentimes on a single political issue) also form to field candidates exclusively in EP elections.
} 
we consider OLS specifications of the form:

$$
\operatorname{lnNumParties}_{c p}=\beta_{0}+\beta_{1} \times \Delta \text { lnSalary }_{c}+\beta_{2} \times E P 7_{p}+\beta_{3} \times E P 7_{p} \times \Delta \operatorname{lnSalary} \text { S }_{c}+\varepsilon_{c p}
$$

where $p \in\{6,7\}$. As Column (1) shows, $\hat{\beta}_{1}=-0.22(p<0.05)$, indicating that, in the crosssection, countries that paid higher salaries to their MEPs in EP6 had more parties field candidates for those positions. The estimate of $\beta_{2}$ is very close to zero, suggesting that in the absence of a salary change, there would have been no temporal trend in the number of parties fielding candidates to the European Parliament. The estimate of $\beta_{3}$ is $0.16(p<0.05)$. The standard deviation of InNumParties in EP6 is $0.37,{ }^{25}$ so $\hat{\beta}_{3}$ implies that doubling MEP salaries would increase the log number of parties by about $29 \%$ of a standard deviation. In Column (2) of Table 5 we add country by EP controls, and in Column (3) we add country fixed effects. The estimate of $\beta_{3}$ is significant in each of the three specifications.

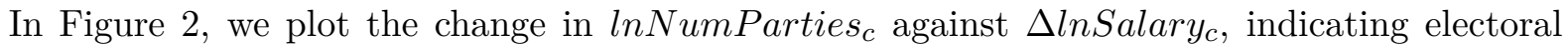
system as open, closed, or ordered. As the figure shows, the positive relationship between the two variables is not driven by extreme observations.

The impact of salary on the number of parties that field a candidate suggests that increasing politicians' salaries provides the electorate with a broader choice of political platforms. As emphasized by the literature on the valuation of new goods (Bresnahan and Gordon 1997), this broader choice set is likely to increase welfare. ${ }^{26}$ Since voters do not express their willingness to pay to have one candidate over another, we obviously cannot compute the associated increase in welfare in monetary terms. ${ }^{27}$ Moreover, an increase in the number of parties in the European Parliament may have other, indirect, benefits besides providing the electorate with new platforms they prefer over the existing ones. For instance, it could be that the presence of competing parties leads the existing parties to become less corrupt or more responsive to voter preferences. ${ }^{28}$

\footnotetext{
${ }^{25}$ This is somewhat different from the overall standard deviation of $\ln N$ umParties reported in Table 1, since that calculation includes observations from both EP6 and EP7.

${ }^{26}$ For a caveat, however, see Kamenica (2008).

${ }^{27}$ One possibility might be to use data on vote shares to estimate the fraction of the electorate whose preferred choice is a new party whose participation was induced by higher salaries, but this approach is not feasible since in many countries there is substantial entry and exit of parties that participate in European politics.

${ }^{28}$ This is analogous to standard arguments in industrial organization. Even if few consumers buy products from a new entrant, the entry can increase consumer welfare by lowering the prices of incumbent firms.
} 
Overall, our three measures of the extensive margin of labor supply, ReRun ${ }_{i p}$, PostVoteQuite P $_{\text {, }}$ and $\operatorname{lnNumParties}$, $_{c}$, suggest that the salary associated with a political office has a substantial impact on the number of candidates willing to hold that office.

\subsection{Intensive margin of labor supply}

In this subsection, we study the effect of pecuniary and non-pecuniary incentives on the intensive margin of labor supply. Our three measures, FractionAbsent ${ }_{i p}$, FractionSignedIn $n_{i p}$, and FractionSignedInAbsent ${ }_{i p}$, are defined in Section 2. We begin with our primary measure of the intensive margin of labor supply, Fraction Absent $t_{i p}$, the fraction of sittings in parliament $p$ during which an MEP cast no votes (abstentions are included as votes cast). In Table 6, we consider OLS specifications of the form:

FractionAbsent $_{i p}=\beta_{0}+\beta_{1} \times \Delta \operatorname{lnSalary}{ }_{c}+\beta_{2} \times E P 7_{p}+\beta_{3} \times E P 7_{p} \times \Delta \operatorname{lnSalary}$ S $_{i p}$.

As noted above, we focus on the first year of each parliament to avoid comparing behaviors across different points in the electoral cycle and further to concentrate on behavior during the period of EP6 that occurred before the salary vote. The coefficient $\beta_{1}$ captures any cross-sectional relationship between pre-harmonization salaries and the tendency of MEPs to be absent. All of the estimates of $\beta_{1}$ are negative, but in each case, the coefficient is imprecisely estimated and statistically insignificant. Estimates of $\beta_{2}$ are also negative but insignificant.

The point estimates on the main coefficient of interest, $\beta_{3}$, are positive and insignificant. In some specifications, the positive estimate is close to conventional significance, but when we include

country fixed effects, the estimated coefficient drops to 0.00, with a standard error of 0.019. Thus, while specifications with sparse controls might suggest that higher salary decreases effort, our preferred specification implies that salary change has no effect. Moreover, as we shall discuss below, any impact of salary on effort is likely to be driven by selection effects.

We now turn to the impact of salary on FractionSignedIn ${ }_{i p}$, the fraction of days an MEP signed the daily register in parliament $p$. We include this specification primarily so we can relate our analysis to the existing literature; as we mentioned earlier, this outcome measure is difficult to 
interpret since it conflates effort (showing up to work) and greed (signing the register even if you are not going to work). In Table 7, we consider OLS specifications of the form:

FractionSignedIn $_{i p}=\beta_{0}+\beta_{1} \times \Delta \operatorname{lnSalary}_{c}+\beta_{2} \times E P 7_{p}+\beta_{3} \times E P 7_{p} \times \Delta \operatorname{lnSalary}_{c}+\varepsilon_{i p} .(5)$

In Column (1), we report the coefficients from the regression in Equation (5). Column (2) adds country by time period controls. Column (3) adds MEP by time period controls. Column (4) adds country fixed effects. In a concurrent paper, Mocan and Altindag (2011) also explore how salary changes induced by the reform in the European Parliament affected the tendency of MEPs to sign the register. Our specification is somewhat different from theirs, but it reveals roughly the same pattern. Like Mocan and Altindag (2011), we find a small negative point estimate on $\beta_{3}$. Our estimates are similar in magnitude to those of Mocan and Altindag (2011), but we find a far lower level of statistical significance, presumably because we cluster our standard errors by country.

Finally, we examine the behavior that was at the root of the scandals we discussed in the introduction: the tendency of MEPs to sign the register and then immediately leave the building. Recall that FractionSignedInAbsent ${ }_{i p}$ is defined as the fraction of those sittings in year $t$ when MEP $i$ signed the register but cast zero votes. In Table 8, we consider an OLS specification of the form:

$$
\begin{aligned}
\text { FractionSignedInAbsent }_{i p}= & \beta_{0}+\beta_{1} \times \Delta \text { lnSalary }_{c}+\beta_{2} \times E P 7_{p} \\
& +\beta_{3} \times E P 7_{p} \times \Delta \text { lnSalary }_{c}+\varepsilon_{i p} .
\end{aligned}
$$

None of the coefficients of interest, $\beta_{1}$ through $\beta_{3}$, is significant in any specification.

Coefficient $\beta_{3}$ in Tables 6 and 8 captures the overall impact (or lack there of) of salary change on the intensive margin of labor supply. These coefficients, however, reflect both a treatment effect (the impact on the MEPs who are in office) and a potential selection effect (the change in the type of MEPs that hold office). In Table 9, we try to disentangle these two effects. In Panel A, we repeat the analyses of Tables 6 and 8 limiting the sample to freshman MEPs in each parliament, while in Panel B we use the sample of incumbent MEPs. To conserve space, we present only specifications with country and individual controls, and those with country fixed effects. Overall, the estimate 
of $\beta_{3}$ is much greater in magnitude and has a smaller standard error in Panel A than in Panel B. This pattern suggests that, to the extent that there is any impact of salary on the intensive margin of labor supply at all, ${ }^{29}$ it stems from a higher salary attracting MEPs who exert less effort rather than from a change in the effort of incumbent MEPs. We further examine the selection effects induced by the salary change in the next subsection.

One possible reason for the limited impact of salaries on the intensive margin is that politicians' motivations to exert effort while in office may be dominated by non-pecuniary considerations. In particular, the desire to perform one's public duty combined with the fear of social sanction may prevent shirking. Following the approach in Fisman and Miguel (2007), we use corruption as a proxy for a country's social norms. Looking back at Tables 6-8, we observe that home-country corruption is consistently associated with lower attendance: MEPs from more corrupt countries are more likely to be absent from roll-call votes; they are less likely to sign the daily register; and conditional on signing the register, they are more likely to be absent. The estimates are large in magnitude. For example, the point estimate on corruption in Table 8 (Column 2) implies that a one standard deviation increase in the corruption level of an MEP's home country increases FractionSignedInAbsent $_{i p}$ (evaluated at the sample mean of 8.0 percent) by about 16 percent.

It is worth noting that our results on corruption are identified from cross-sectional variation; unsurprisingly, when we include country fixed effects, the impact of corruption is inconsistent in magnitude and significance, as within-country variation in corruption ratings is essentially noise. In contrast, we take advantage of a plausibly exogenous salary change to identify the sensitivity of MEP behavior to financial incentives. Hence, our evidence on the effects of social norms may be more vulnerable to omitted variable bias. That said, the coefficient on corruption remains very stable in magnitude and significance as we include additional covariates. This stability suggests that if the observable characteristics in our data are representative of the unobservables, omitted variable bias is unlikely to drive our results (Altonji, Elder, and Taber 2005).

\footnotetext{
${ }^{29}$ Note that $\beta_{3}$ is not significant in any specification once we include country fixed effects.
} 


\subsection{Quality of MEPs}

The fact that higher wages induce more individuals to seek a political office does not by itself imply that the quality of elected officials will increase. In fact, as discussed in the introduction, there are several theoretical models which suggest that a higher salary may lower the quality of candidates and elected politicians. Moreover, Table 9 presented suggestive evidence that higher salary attracts MEPs that are more prone to absenteeism and shirking. In this subsection, we analyze the impact of the salary change on the quality of elected MEPs as proxied by the global rankings of the undergraduate institutions they attended. Many studies have found that individuals who attend more selective colleges have greater permanent income. For example, Kane (1998) shows that, in the United States, attending a college with a 100 point higher average SAT is associated with 3 to 7 percent higher earnings later in life. ${ }^{30}$ Hence, MEPs who attended a more selective college are likely to be more productive workers, and as long as market skill is positively correlated with political skill, this would also mean they are likely to be more effective politicians. Moreover, college selectivity of an MEP strongly predicts reelection conditional on rerunning - a pattern that continues to hold if we include country fixed effects and/or controls for other MEP characteristics. ${ }^{31}$ This correlation further supports our view that college selectivity is a good proxy for MEPs' quality, particularly in the eyes of voters.

In Section 2, we describe the construction of the variable FractionRankedCollege $e_{c p}$. In Table 10, we consider OLS specifications of the form:

$$
\text { FractionRankedCollege }_{c p}=\beta_{0}+\beta_{1} \times \Delta \operatorname{lnSalary} y_{c}+\beta_{2} \times E P 7_{p}+\beta_{3} \times E P 7_{p} \times \Delta \operatorname{lnSalary} y_{c}+\varepsilon_{c p}
$$

In Columns (1) through (3), we simply drop the $10 \%$ of MEPs where we could not identify their undergraduate institutions. In Column (1), coefficient $\beta_{1}$ is imprecisely estimated. Estimate of $\beta_{2}$ is positive and significant $(p<0.01)$ which means that, net of the impact of salary change, the quality of MEPs in EP7 was greater than in EP6. The estimate of $\beta_{3}$ is $-0.06(p<0.01)$. This implies that doubling an MEP's salary reduces the likelihood than an elected MEP attended a

\footnotetext{
${ }^{30}$ Most of the literature on this topic strives to disentangle the causal impact of college selectivity on future earnings from selection effects (e.g., Dale and Krueger 2002). For our purposes, however, it does not matter whether college selectivity causes or simply predicts high permanent income.

${ }^{31}$ Results available on request.
} 
top university by 4.2 percentage points. Given that around $30 \%$ of MEPs overall attend a top university, this is a reduction of 14 percent. In Column (2) we include country by EP controls. The estimate of $\beta_{3}$ is unaffected. Column (3) includes country fixed effects. This makes the coefficient less precisely estimated, and thus no longer significant at the 5 percent level $(p=0.079)$. In Columns (4) through (6) we redefine our outcome variable FractionRankedCollege $e_{c p}$ by including

all MEPs and coding those with missing education data as having gone to an unranked school. This alternative specification slightly strengthens our results.

Overall, our results provide support for the view, emphasized by theoretical work discussed in the introduction, that higher salaries might decrease the quality of elected officials. Thus, at least in the context of the European Parliament, this negative selection effect needs to be weighed against the benefits of increased competition suggested by the results in Subsection 3.1.

\subsection{Intensive margin of labor supply and election outcomes}

Finally, we turn to the relationship between absenteeism and shirking, on one hand, and the likelihood that an incumbent MEP gets elected conditional on running for reelection on the other. In Table 11, we consider a linear probability model:

$$
\text { ReElected }_{i p}=\beta_{0}+\beta_{1} \times \text { AttendanceRecord }_{i p-1}+\varepsilon_{i p}
$$

The sample is the set of all MEPs who served in EP5 and ran for reelection for EP6 and MEPs who served in EP6 and ran for reelection for EP7. ReElected Rip $_{i}$ is an indicator variable equal to 1 if the MEP was elected to parliament $p$. We consider the same three measures of AttendanceRecord $d_{i p-1}$ as in the previous subsection, but incorporate votes in all years, since there is no clear reason to limit the sample to the first year of each parliament. In Columns (1), (3), and (5), we report the coefficients from the regressions in Equation (8). In Columns (2), (4), and (6), we add controls for EP7, MEP by EP controls, and country fixed effects. Across all specifications, we find that MEPs with better attendance records are significantly more likely to be reelected at the $5 \%$ level. The only exception is the estimate in Column (4) where the point estimate on FractionSignedIn $n_{i p-1}$ is only significant at the $10 \%$ level. Of course, the results in Table 11 should be interpreted with 
considerable caution since we are looking at reelection results conditional on the fact that the MEP

chose to run for reelection. With that caveat in mind, these results provide suggestive evidence that voters prefer MEPs who exert more effort while in office.

If this relationship between electoral success and effort is assumed to be causal, it becomes more difficult to reconcile our two earlier findings: higher salaries make the office of MEP more desirable but do not decrease shirking. It may be, however, that the increased electoral incentive is insufficient to induce higher effort, or that MEPs are myopic in their behavior between elections.

\subsection{Endogeneity concerns}

The validity of the analysis in the preceding subsections rests on the assumption that the timing of the change in salary regime is uncorrelated with a change in other factors that differentially affect MEPs from low-salary and high-salary countries. One concern would be that the salary equalization proposal got passed precisely when the MEPs from low-salary countries were more likely to run for reelection and thus particularly motivated to raise future salaries. There are two sets of facts that alleviate this concern. First, this explanation could not account for the increased number of parties that field a candidate when salaries increase. If anything, facing more motivated incumbents would be a deterrent that would lead to fewer challengers. Second, as we report in Table 12, whether an MEP voted for or against salary harmonization is uncorrelated with whether the regime change would raise or lower her salary. Specifically, we let VoteForSalaryChange $i$ be an indicator variable for whether MEP $i$ voted for salary harmonization and we consider a linear probability model:

$$
\text { VoteForSalaryChange }{ }_{i}=\beta_{0}+\beta_{1} \times \Delta \ln \text { Salary }_{c}+\varepsilon_{i} \text {. }
$$

Whether we consider this baseline specification (Column 1), add MEP-level controls (Column 2), or further include country-level controls (Column 3), the estimate of $\beta_{1}$ is small and insignificant. Similarly, if we include VoteForSalaryChange ${ }_{i}$ as a control to any of the regressions considered above, the results are unchanged. 


\section{Conclusion}

We provide evidence on the impact of pecuniary and non-pecuniary incentives on both the extensive and the intensive margins of politicians' labor supply. We take advantage of a unique set of circumstances - a salary reform in the European Parliament that allows for a credible identification of financial motives, and the cross-country nature of the parliament itself which provides variation in the norms of politicians' home communities. We also introduce an innovative measure of politicians' shirking, based on signing the attendance register to collect a daily allowance, but not participating in session votes.

Our results imply that a higher salary: (i) attracts more candidates and more parties, (ii) has no substantial impact on effort exerted while in office, and (iii) reduces the quality of elected MEPs. Meanwhile, non-pecuniary factors seem to play an important role in inducing politicians to exert effort while in office.

There are many questions raised by these results. Most obviously, it would be important to know the extent to which our set of findings would carry over to politicians in other places or other levels of government. Furthermore, while we find that home-country social norms influence the intensive margin of labor supply, we are unable to distinguish whether these norms operate through politicians' internal motivations or through social pressure from the electorate. By carefully considering how the media coverage of scandals affects MEPs' behavior, one might better understand the relative importance of these two channels. It may also be useful to understand whether political institutions such as term limits and electoral rules interact with pecuniary and non-pecuniary motives in influencing politicians' behavior. Finally, given our preliminary results on the role of selection effects in the behavior of elected MEPs, it will be important to assess the impacts of salary changes in the longer run. 


\section{References}

[1] Altonji, Joseph G., Todd E. Elder, and Christopher R. Taber, "Selection on Observed and Unobserved Variables: Assessing the Effectiveness of Catholic Schools," Journal of Political Economy, 113 (2005), 151-184.

[2] Besley, Timothy, "Paying Politicians: Theory and Evidence," Journal of the European Economic Association, 2 (2004), 193-215.

[3] Bresnahan, Timothy F., and Robert J. Gordon, eds., The Economics of New Goods, National Bureau of Economic Research Studies in Income and Wealth, Vol. 58. (Chicago, IL: University of Chicago Press, 1997).

[4] Caselli, Francesco, and Massimo Morelli, "Bad Politicians," Journal of Public Economics, 88 (2004), 759-782.

[5] Corbett, Richard, Francis Jacobs, and Michael Shackleton, The European Parliament, 6th ed. (London, United Kingdom: John Harper Publishing, 2005).

[6] Dale, Stacy B., and Alan B. Krueger, "Estimating the Payoff to Attending a More Selective College: An Application of Selection on Observables and Unobservables," Quarterly Journal of Economics, 117 (2002), 1491-1527.

[7] Di Tella, Rafael, and Raymond Fisman, "Are Politicians Really Paid Like Bureaucrats?," Journal of Law and Economics, 47 (2004), 477-513.

[8] Diermeier, Daniel, Michael P. Keane, and Antonio Merlo, "A Political Economy Model of Congressional Careers," American Economic Review, 95 (2005), 347-373.

[9] Ferraz, Claudio, and Frederico Finan, "Motivating Politicians: The Impacts of Monetary Incentives on Quality and Performance," Working Paper, 2009.

[10] Fisman, Raymond, and Edward Miguel, "Corruption, Norms, and Legal Enforcement: Evidence from Diplomatic Parking Tickets," Journal of Political Economy, 115 (2007), $1020-1048$. 
[11] Gagliarducci, Stefano, and Tommaso Nannicini, "Do Better Paid Politicians Perform Better? Disentangling Incentives from Selection," Journal of the European Economic Association, forthcoming.

[12] Gagliarducci, Stefano, Tommaso Nannicini, and Paolo Naticchioni, "Moonlighting Politicians," Journal of Public Economics, 94 (2010), 688-699.

[13] Groseclose, Timothy, and Keith Krehbiel, "Golden Parachutes, Rubber Checks, and Strategic Retirements from the 102d House," American Journal of Political Science, 38 (1994), 75-99.

[14] Hall, Richard L., and Robert P. van Houweling, "Avarice and Ambition in Congress: Representatives' Decisions to Run or Retire from the U.S. House," American Political Science Review, 89 (1995), 121-136.

[15] Hix, Simon, and Sara Hagemann, "Could Changing the Electoral Rules Fix European Parliament Elections?," Politique Européenne, 28.2 (2009), 37-52.

[16] Hix, Simon, Abdul G. Noury, and Gérard Roland, Democratic Politics in the European Parliament. (New York, NY: Cambridge University Press, 2007).

[17] Kahneman, Daniel, and Amos Tversky, "Prospect Theory: An Analysis of Decision under Risk," Econometrica, 47 (1979), 263-292.

[18] Kamenica, Emir, "Contextual Inference in Markets: On the Informational Content of Product Lines," American Economic Review, 98 (2008), 2127-2149.

[19] Kane, Thomas J., "Racial and Ethnic Preferences in College Admission," in The BlackWhite Test Score Gap, Christopher Jencks and Meredith Phillips, eds. (Washington, DC: Brookings Institution Press, 1998).

[20] Kaufmann, Daniel, Aart Kraay, and Massimo Mastruzzi, "The Worldwide Governance Indicators: Methodology and Analytical Issues," Brookings Working Paper, 2010. 
[21] Keane, Michael P., and Antonio Merlo, "Money, Political Ambition, and the Career Decisions of Politicians," American Economic Journal: Microeconomics, 2 (2010), $186-215$.

[22] Kotakorpi, Kaisa, and Panu Poutvaara, "Pay for Politicians and Candidate Selection: An Empirical Analysis," Journal of Public Economics, 95 (2011), 877-885.

[23] Mattozzi, Andrea, and Antonio Merlo, "Political Careers or Career Politicians?," Journal of Public Economics, 92 (2008), 597-608.

[24] Messner, Matthias, and Mattias K. Polborn, "Paying Politicians," Journal of Public Economics, 88 (2004), 2423-2445.

[25] Mocan, Naci H., and Duha T. Altindag, "Is Leisure a Normal Good? Evidence from the European Parliament", NBER Working Paper No. 17329, 2011.

[26] Poutvaara, Panu, and Tuomas Takalo, "Candidate Quality," International Tax and Public Finance, 14 (2007), 7-27. 


\section{Figures and Tables}

FIGURE 1

Change in Fraction of MEPs Who Ran for Reelection vs. Change in Salary

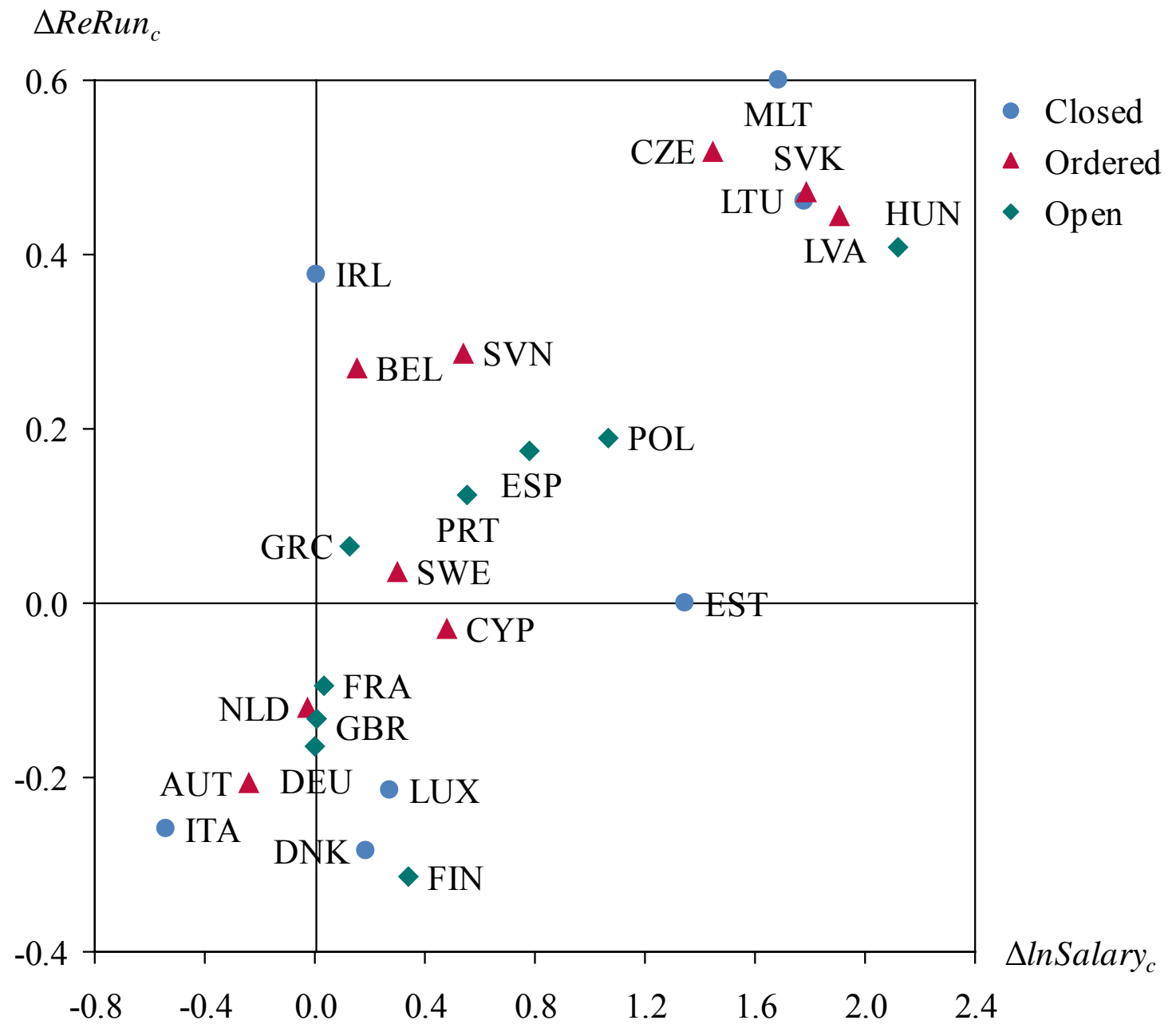

$\operatorname{ReRun}_{i p}$ is an indicator variable for whether MEP $i$ who served in parliament $p-1$ ran for reelection for parliament p. $R^{2} R u n_{c p}$ is the mean of ReRun $i p$ for MEPs from country c. $\Delta R e R u n_{c}$ is ReRun ${ }_{c 7}$ minus ReRun $_{c 6}$. $\Delta \operatorname{lnSalary}_{c}$ is defined as the logarithm of 84,000 (the post-change uniform salary level) minus the logarithm of the salary for MEPs from country $c$ as of December 2004. Closed, ordered, and open refer to the type of electoral system in each country. Countries are labeled with their ISO codes: Austria (AUT), Belgium (BEL), Cyprus (CYP), Czech Republic (CZE), Denmark (DNK), Estonia (EST), Finland (FIN), France (FRA), Germany (DEU), Greece (GRC), Hungary (HUN), Ireland (IRL), Italy (ITA), Latvia (LVA), Lithuania (LTU), Luxembourg (LUX), Malta (MLT), Netherlands (NLD), Poland (POL), Portugal (PRT), Slovakia (SVK), Slovenia (SVN), Spain (ESP), Sweden (SWE), and United Kingdom (GBR). 
FIGURE 2

Change in Number of Parties Fielding Candidates vs. Change in Salary

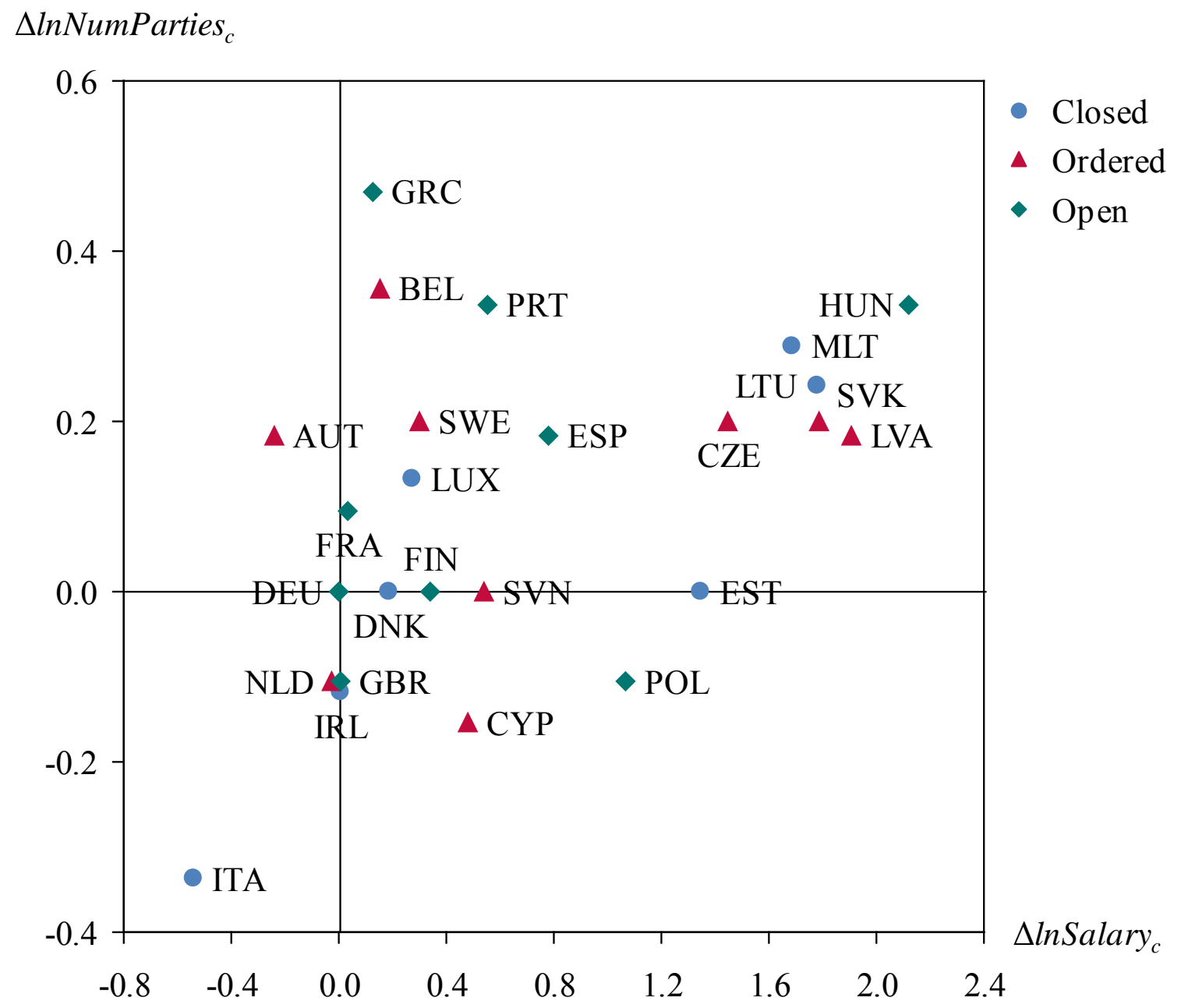

InNumParties $_{c p}$ is the logarithm of the number of parties in country $c$ that received at least $0.5 \%$ of the vote for parliament $p$. $\Delta$ InNumParties ${ }_{c}$ is defined as InNumParties ${ }_{c 7}$ minus InNumParties In. $_{\text {InSalary }}$ is the logarithm of 84,000 (the post-change uniform salary level) minus the logarithm of the salary for MEPs from country $c$ as of December 2004. Closed, ordered, and open refer to the type of electoral system in each country. Countries are labeled with their ISO codes: Austria (AUT), Belgium (BEL), Cyprus (CYP), Czech Republic (CZE), Denmark (DNK), Estonia (EST), Finland (FIN), France (FRA), Germany (DEU), Greece (GRC), Hungary (HUN), Ireland (IRL), Italy (ITA), Latvia (LVA), Lithuania (LTU), Luxembourg (LUX), Malta (MLT), Netherlands (NLD), Poland (POL), Portugal (PRT), Slovakia (SVK), Slovenia (SVN), Spain (ESP), Sweden (SWE), and United Kingdom (GBR). 
TABLE 1

Summary Statistics

\begin{tabular}{|c|c|c|c|c|c|}
\hline & Mean & Std. Dev. & Min & Max & Obs. \\
\hline \multicolumn{6}{|c|}{ A. MEP-Parliament Variables } \\
\hline$A g e_{i p}$ & 54.32 & 9.96 & 22 & 87 & 1,608 \\
\hline$A g e S q_{i p} / 100$ & 30.50 & 10.73 & 4.84 & 75.69 & 1,608 \\
\hline Tenure $_{i p}$ & 7.12 & 5.93 & 0 & 29 & 1,608 \\
\hline ReRun $_{i p}$ & 0.572 & 0.495 & 0 & 1 & 1,592 \\
\hline ReElected $_{i p}$ & 0.699 & 0.459 & 0 & 1 & 967 \\
\hline PostVoteQuit $_{i p}$ & 0.111 & 0.314 & 0 & 1 & 1,608 \\
\hline FractionAbsent $_{i p}$ & 0.184 & 0.151 & 0 & 1 & 1,417 \\
\hline FractionSignedIn $_{i p}$ & 0.884 & 0.134 & 0 & 1 & 1,417 \\
\hline FractionSignedInAbsent $_{i p}$ & 0.080 & 0.079 & 0 & 1 & 1,410 \\
\hline \multicolumn{6}{|c|}{ B. Country-Parliament Variables } \\
\hline InNumParties $_{c p}$ & 2.124 & 0.345 & 1.099 & 2.996 & 50 \\
\hline FractionRankedCollege $_{c p}$ & 0.330 & 0.250 & 0 & 1 & 50 \\
\hline \multicolumn{6}{|l|}{ C. Country Variables } \\
\hline$\Delta$ InSalary & 0.645 & 0.767 & -0.540 & 2.120 & 25 \\
\hline $\ln G D P P C_{C}$ & 9.598 & 0.702 & 8.492 & 10.859 & 25 \\
\hline Corruption $_{c}$ & -1.175 & 0.631 & -2.220 & -0.291 & 25 \\
\hline
\end{tabular}

A. MEP-Parliament Variables. Age $e_{i p}$ and $A g e S q_{i p} / 100$ are based on the age of MEP $i$ in the first year of parliament $p$. Tenure $i p$ is the number of years MEP $i$ has been in office as of the first year of parliament $p$. ReRun $n_{i p}$ is an indicator variable that equals 1 if MEP $i$ served in parliament $p-1$ and ran for reelection for parliament $p$. ReRun $_{i p}$ is missing for 16 observations. ReElected $i p$ is an indicator variable for whether MEP $i$ served in parliament $p$ - 1 and was reelected to parliament $p$. PostVoteQuit ip is an indicator variable that equals 1 if MEP $i$ served in parliament $p$ and quit before completing the parliamentary term at some point after June 23rd of the second calendar year of parliament $p$. FractionAbsent $t_{i p}$ is the fraction of sittings in the first parliament year of parliament $p$ during which MEP $i$ did not participate in any of the roll-call votes. FractionSignedIn $n_{i p}$ is the fraction of sittings in the first parliament year of parliament $p$ during which MEP $i$ signed the daily register. FractionSignedInAbsent $t_{i p}$ is the fraction of sittings during which MEP $i$ signed the register in the first parliament year of parliament $p$ that she did not participate in any of the roll-call votes. FractionSignedInAbsent ${ }_{i p}$ is missing for MEPs who never signed in.

B. Country-Parliament Variables. InNumParties ${ }_{c p}$ is defined as the logarithm of the number of parties in country $c$ that received at least $0.5 \%$ of the vote for parliament $p$. FractionRankedCollege ${ }_{c p}$ is the fraction of MEPs from country $c$ in parliament $p$ who attended a college ranked in the top 500 by the 2010 Academic Ranking of World Universities.

C. Country Variables. InSalary $_{c}$ is defined as the logarithm of 84,000 (the post-change uniform salary level) minus the logarithm of the salary for MEPs from country $c$ as of December 2004. InGDPPC $C_{c}$ is the logarithm of the GDP per capita in constant 2000 U.S. dollars in country $c$ and year 2005 from the World Development Indicators. Corruption $_{c}$ is the measure of corruption in country $c$ and year 2005 based on Kaufmann et al. (2010). 
TABLE 2

Gross Annual Salaries of MEPs by Country

\begin{tabular}{lcllc}
\hline \hline Country & Annual Salary $(€)$ & & Country & Annual Salary $(€)$ \\
\cline { 5 - 5 } Austria & 106,583 & & Latvia & 12,518 \\
Belgium & 72,018 & & Lithuania & 14,197 \\
Cyprus & 52,041 & & Luxembourg & 63,791 \\
Czech Republic & 19,774 & & Malta & 15,534 \\
Denmark & 69,816 & & Netherlands & 86,126 \\
Estonia & 21,864 & & Poland & 28,860 \\
Finland & 59,640 & & Portugal & 48,286 \\
France & 81,273 & & Slovakia & 14,085 \\
Germany & 84,108 & & Slovenia & 48,815 \\
Greece & 73,850 & & Spain & 38,396 \\
Hungary & 10,080 & Sweden & 62,069 \\
Ireland & 83,712 & United Kingdom & 83,312 \\
Italy & 144,084 & & \\
\hline \hline
\end{tabular}

Annual pre-tax salary in nominal $€$ as of December, 2004. Source: Corbett et al. (2005). 
TABLE 3

Effect of Salary Change on Willingness of Incumbent MEPs to Seek Reelection

Dependent variable: $R e R u n_{i p}$

\begin{tabular}{lcccc}
\hline \hline & $(1)$ & $(2)$ & $(3)$ & $(4)$ \\
\hline$\Delta$ InSalary $_{c}$ & $-0.1757^{* *}$ & $-0.1603^{*}$ & $-0.1698^{* *}$ & \\
& $(0.0382)$ & $(0.0604)$ & $(0.0578)$ & \\
$E P 7_{p}$ & $-0.0902^{* *}$ & $-0.0874^{* *}$ & $-0.0715^{* *}$ & $-0.0800^{* *}$ \\
& $(0.0215)$ & $(0.0238)$ & $(0.0224)$ & $(0.0241)$ \\
$E P 7_{p} \times \Delta$ InSalary $_{c}$ & $0.3010^{* *}$ & $0.3127^{* *}$ & $0.3323^{* *}$ & $0.3290^{* *}$ \\
& $(0.0250)$ & $(0.0312)$ & $(0.0313)$ & $(0.0407)$ \\
InGDPPC $_{c p}$ & & -0.0417 & 0.0115 & 0.0571 \\
& & $(0.0835)$ & $(0.0857)$ & $(0.2745)$ \\
Corruption $_{c p}$ & & $-0.1200^{*}$ & -0.0953 & 0.1792 \\
& & $(0.0551)$ & $(0.0536)$ & $(0.0921)$ \\
Age $_{i p}$ & & & $0.0403^{* *}$ & $0.0417^{* *}$ \\
& & & $(0.0098)$ & $(0.0100)$ \\
AgeSq $_{i p} / 100$ & & & $-0.0439^{* *}$ & $-0.0448^{* *}$ \\
InTenure $_{i p}$ & & & $(0.0101)$ & $(0.0102)$ \\
& & & -0.0279 & -0.0426 \\
Country Fixed Effects $_{\text {Observations }}$ & No & No & $(0.0214)$ & $(0.0269)$ \\
$R^{2}$ & 1,592 & 1,592 & 1,592 & No \\
\hline \hline
\end{tabular}

Linear probability model; robust standard errors clustered by country in parentheses. The level of observation is MEP-Parliament for EP6 and EP7. The sample consists of all MEPs in EP5 and those who joined EP6 before the vote on salary change. The dependent variable in all regressions is ReRun ${ }_{i p}$, an indicator variable that equals 1 if MEP $i$ served in parliament $p-1$ and ran for reelection for parliament $p$. $\Delta$ lnSalary $y_{c}$ is defined as the logarithm of 84,000 (the post-change uniform salary level) minus the logarithm of the salary for MEPs from country $c$ as of December 2004. $E P 7_{p}$ is an indicator variable for whether $p=7$. $\operatorname{lnGDPPC}_{c p}, \operatorname{Corruption}_{c p}, \mathrm{Age}_{i p}, \mathrm{AgeSq}_{i p} / 100$, and InTenure $_{i p}$ are measured in the last year of parliament $p-1$ and are defined in Table 1.

* significant at 5 percent; ** significant at 1 percent. 
TABLE 4

Effect of Salary Change on MEPs Quitting Before Completing Term After Vote Dependent variable: PostVoteQuitip

\begin{tabular}{|c|c|c|c|c|}
\hline & (1) & (2) & (3) & (4) \\
\hline$\Delta \operatorname{lnSalary}_{c}$ & $\begin{array}{c}-0.0327 \\
(0.0176)\end{array}$ & $\begin{array}{c}0.0275 \\
(0.0399)\end{array}$ & $\begin{array}{c}0.0536 \\
(0.0317)\end{array}$ & \\
\hline$E P 6_{p}$ & $\begin{array}{c}0.0485 \\
(0.0404)\end{array}$ & $\begin{array}{c}0.0418 \\
(0.0350)\end{array}$ & $\begin{array}{c}0.0319 \\
(0.0329)\end{array}$ & $\begin{array}{c}0.0133 \\
(0.0253)\end{array}$ \\
\hline$E 6_{p} \times \Delta$ InSalary $_{c}$ & $\begin{array}{c}-0.0317 \\
(0.0439)\end{array}$ & $\begin{array}{c}-0.0508 \\
(0.0410)\end{array}$ & $\begin{array}{c}-0.0892 * \\
(0.0332)\end{array}$ & $\begin{array}{l}-0.1260 * * \\
(0.0317)\end{array}$ \\
\hline $\ln G D P P C_{c p}$ & & $\begin{array}{c}0.1392 * \\
(0.0557)\end{array}$ & $\begin{array}{c}0.1129 \\
(0.0615)\end{array}$ & $\begin{array}{c}0.4963 * \\
(0.2182)\end{array}$ \\
\hline Corruption $_{c p}$ & & $\begin{array}{l}0.1104 * * \\
(0.0341)\end{array}$ & $\begin{array}{c}0.1251 * * \\
(0.0336)\end{array}$ & $\begin{array}{l}0.4651^{* *} \\
(0.0986)\end{array}$ \\
\hline$A g e_{i p}$ & & & $\begin{array}{c}-0.0089 \\
(0.0076)\end{array}$ & $\begin{array}{c}-0.0083 \\
(0.0069)\end{array}$ \\
\hline $\mathrm{AgeS}_{\text {ip }} / 100$ & & & $\begin{array}{c}0.0052 \\
(0.0074)\end{array}$ & $\begin{array}{c}0.0047 \\
(0.0068)\end{array}$ \\
\hline lnTenure $_{i p}$ & & & $\begin{array}{c}0.0654 * * \\
(0.0195)\end{array}$ & $\begin{array}{l}0.0567 * * \\
(0.0166)\end{array}$ \\
\hline Country Fixed Effects & No & No & No & Yes \\
\hline Observations & 1,608 & 1,608 & 1,608 & 1,608 \\
\hline$R^{2}$ & 0.015 & 0.028 & 0.047 & 0.087 \\
\hline
\end{tabular}

Linear probability model; robust standard errors clustered by country in parentheses. The level of observation is MEP-Parliament for EP5 and EP6. The sample consists of all MEPs in EP5 and those who joined EP6 before the vote on salary change. The dependent variable in all regressions is PostVoteQuit $t_{i p}$, an indicator variable that equals 1 if MEP $i$ quit her job before completing the parliamentary term at some point after June 23rd of the second calendar year of parliament $p$. For $p=6$, the variable indicates whether the MEP quit the parliament at some point after the vote on the salary change. For $p=5$, the variable indicates whether MEP $i$ quit the parliament during the same segment of the electoral cycle but before the salary change had been introduced. $\Delta$ lnSalary $_{c}$ is defined as the logarithm of 84,000 (the post-change uniform salary level) minus the logarithm of the salary for MEPs from country

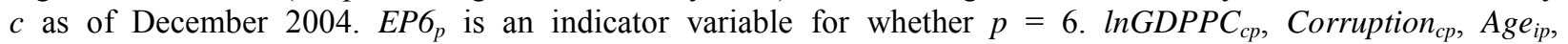
AgeSq $_{i p} / 100$, and $\operatorname{lnTenure}{ }_{i p}$ are measured in the last year of parliament $p-1$ and are defined in Table 1.

* significant at 5 percent; ** significant at 1 percent. 
TABLE 5

Effect of Salary Change on Number of Parties Fielding Candidates

Dependent variable: InNumParties ${ }_{c p}$

\begin{tabular}{lccc}
\hline \hline & $(1)$ & $(2)$ & $(3)$ \\
\hline InSalary $_{c}$ & $-0.2161^{*}$ & -0.3009 & \\
& $(0.0966)$ & $(0.1912)$ & \\
$E P 7_{p}$ & -0.0159 & -0.0230 & 0.0734 \\
& $(0.0564)$ & $(0.0703)$ & $(0.1144)$ \\
EP7 $_{p} \times \Delta$ InSalary $_{c}$ & $0.1570^{*}$ & $0.1691^{*}$ & $0.2168^{*}$ \\
& $(0.0627)$ & $(0.0706)$ & $(0.1037)$ \\
$\operatorname{lnGDPPC}_{c p}$ & & -0.0756 & -0.7212 \\
& & $(0.2636)$ & $(1.0365)$ \\
Corruption $_{c p}$ & & 0.0622 & -0.1652 \\
& & $(0.1370)$ & $(0.4072)$ \\
Country Fixed Effects $_{\text {Observations }}$ & No & No & Yes \\
$R^{2}$ & 50 & 50 & 50 \\
\hline \hline
\end{tabular}

OLS; robust standard errors clustered by country in parentheses. The level of observation is Country-Parliament for

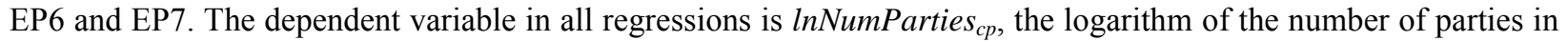
country $c$ that fielded a candidate and received at least $0.5 \%$ of the vote for candidacy to parliament $p . \Delta \operatorname{lnSalary}_{c}$ is defined as the logarithm of 84,000 (the post-change uniform salary level) minus the logarithm of the salary for MEPs from country $c$ as of December 2004. $E P 7_{p}$ is an indicator variable for whether $p=7$. $\ln G D P P C_{c p}$ and Corruption $_{c p}$ are measured in the last year of parliament $p-1$ and are defined in Table 1.

* significant at 5 percent; ** significant at 1 percent. 
TABLE 6

Effect of Salary Change on Absenteeism

Dependent variable: FractionAbsent ${ }_{i p}$

\begin{tabular}{|c|c|c|c|c|}
\hline & (1) & (2) & (3) & (4) \\
\hline$\Delta$ InSalary $_{c}$ & $\begin{array}{c}-0.0380 \\
(0.0280)\end{array}$ & $\begin{array}{c}-0.0235 \\
(0.0348)\end{array}$ & $\begin{array}{c}-0.0244 \\
(0.0351)\end{array}$ & \\
\hline$E P 7_{p}$ & $\begin{array}{c}-0.0029 \\
(0.0224)\end{array}$ & $\begin{array}{c}-0.0139 \\
(0.0245)\end{array}$ & $\begin{array}{c}-0.0137 \\
(0.0243)\end{array}$ & $\begin{array}{c}-0.0046 \\
(0.0119)\end{array}$ \\
\hline$E P 7_{p} \times \Delta \operatorname{lnSalary}{ }_{c}$ & $\begin{array}{c}0.0476 \\
(0.0256)\end{array}$ & $\begin{array}{c}0.0482 \\
(0.0296)\end{array}$ & $\begin{array}{c}0.0453 \\
(0.0296)\end{array}$ & $\begin{array}{c}0.0044 \\
(0.0185)\end{array}$ \\
\hline $\ln G D P P C_{c p}$ & & $\begin{array}{c}0.0490 \\
(0.0427)\end{array}$ & $\begin{array}{c}0.0422 \\
(0.0446)\end{array}$ & $\begin{array}{c}0.5084 * \\
(0.1935)\end{array}$ \\
\hline Corruption $_{c p}$ & & $\begin{array}{c}0.0573 * * \\
(0.0188)\end{array}$ & $\begin{array}{c}0.0571^{* *} \\
(0.0198)\end{array}$ & $\begin{array}{c}-0.0303 \\
(0.0757)\end{array}$ \\
\hline$A g e_{i p}$ & & & $\begin{array}{c}-0.0059 \\
(0.0034)\end{array}$ & $\begin{array}{c}-0.0056 \\
(0.0033)\end{array}$ \\
\hline $\mathrm{AgeS}_{i p} / 100$ & & & $\begin{array}{c}0.0059 \\
(0.0033)\end{array}$ & $\begin{array}{c}0.0057 \\
(0.0032)\end{array}$ \\
\hline InTenure $_{i p}$ & & & $\begin{array}{c}0.0081 \\
(0.0041)\end{array}$ & $\begin{array}{c}0.0091 * \\
(0.0034)\end{array}$ \\
\hline Country Fixed Effects & No & No & No & Yes \\
\hline Observations & 1,417 & 1,417 & 1,417 & 1,417 \\
\hline$R^{2}$ & 0.018 & 0.041 & 0.047 & 0.097 \\
\hline
\end{tabular}

OLS; robust standard errors clustered by country in parentheses. The level of observation is MEP-Parliament for EP6 and EP7. The sample consists of all MEPs in EP6 and EP7. The dependent variable in all regressions is FractionAbsent $t_{i p}$, the fraction of sittings in the first parliament year of parliament $p$ during which MEP $i$ did not participate in any of the roll-call votes. $\Delta$ InSalary $_{c}$ is defined as the logarithm of 84,000 (the post-change uniform salary level) minus the logarithm of the salary for MEPs from country $c$ as of December 2004. $E P 7_{p}$ is an indicator variable for whether $p=7$. $I n G D P P C_{c p}$, Corruption $_{c p}$, Age $_{i p}$, AgeSq $_{i p} / 100$, and $\operatorname{lnTenure}_{i p}$ are measured in the first year of parliament $p$ and are defined in Table $1 . *$ significant at 5 percent; ** significant at 1 percent. 
TABLE 7

Effect of Salary Change on Signing the Register

Dependent variable: FractionSignedIn $n_{i p}$

\begin{tabular}{|c|c|c|c|c|}
\hline & (1) & (2) & (3) & (4) \\
\hline$\Delta$ InSalary $_{c}$ & $\begin{array}{c}0.0346 \\
(0.0197)\end{array}$ & $\begin{array}{c}0.0117 \\
(0.0283)\end{array}$ & $\begin{array}{c}0.0126 \\
(0.0282)\end{array}$ & \\
\hline$E P 7_{p}$ & $\begin{array}{c}0.0064 \\
(0.0139)\end{array}$ & $\begin{array}{c}0.0157 \\
(0.0158)\end{array}$ & $\begin{array}{c}0.0163 \\
(0.0157)\end{array}$ & $\begin{array}{c}0.0122 \\
(0.0097)\end{array}$ \\
\hline$E P 7_{p} \times \Delta \operatorname{lnSalary}{ }_{c}$ & $\begin{array}{c}-0.0283 \\
(0.0147)\end{array}$ & $\begin{array}{c}-0.0277 \\
(0.0176)\end{array}$ & $\begin{array}{c}-0.0259 \\
(0.0175)\end{array}$ & $\begin{array}{c}-0.0042 \\
(0.0141)\end{array}$ \\
\hline $\ln G D P P C_{c p}$ & & $\begin{array}{c}-0.0555 \\
(0.0348)\end{array}$ & $\begin{array}{c}-0.0515 \\
(0.0370)\end{array}$ & $\begin{array}{c}-0.2953 \\
(0.1646)\end{array}$ \\
\hline Corruption $_{c p}$ & & $\begin{array}{c}-0.0478 * * \\
(0.0169)\end{array}$ & $\begin{array}{c}-0.0488^{*} \\
(0.0176)\end{array}$ & $\begin{array}{c}-0.0071 \\
(0.0580)\end{array}$ \\
\hline$A g e_{i p}$ & & & $\begin{array}{c}0.0081 * \\
(0.0032)\end{array}$ & $\begin{array}{c}0.0074^{*} \\
(0.0030)\end{array}$ \\
\hline $\mathrm{AgeS}_{i p} / 100$ & & & $\begin{array}{c}-0.0077^{*} \\
(0.0032)\end{array}$ & $\begin{array}{c}-0.0071 * \\
(0.0031)\end{array}$ \\
\hline InTenure $_{i p}$ & & & $\begin{array}{c}-0.0071 \\
(0.0038)\end{array}$ & $\begin{array}{c}-0.0081 * \\
(0.0037)\end{array}$ \\
\hline Country Fixed Effects & No & No & No & Yes \\
\hline Observations & 1,417 & 1,417 & 1,417 & 1,417 \\
\hline$R^{2}$ & 0.017 & 0.032 & 0.041 & 0.078 \\
\hline
\end{tabular}

OLS; robust standard errors clustered by country in parentheses. The level of observation is MEP-Parliament for EP6 and EP7. The sample consists of all MEPs in EP6 and EP7. The dependent variable in all regressions is FractionSignedIn $_{i p}$, the fraction of sittings in the first parliament year of parliament $p$ during which MEP $i$ signed the daily register. $\Delta$ InSalary $_{c}$ is defined as the logarithm of 84,000 (the post-change uniform salary level) minus the logarithm of the salary for MEPs from country $c$ as of December 2004. EP7 $p$ is an indicator variable for whether $p=$ 7. $\ln G D P P C_{c p}$, Corruption $_{c p}$, Age $_{i p}$, AgeSq $_{i p} / 100$, and InTenure $_{i p}$ are measured in the first year of parliament $p$ and are as defined in Table $1 .{ }^{*}$ significant at 5 percent; $* *$ significant at 1 percent. 
TABLE 8

Effect of Salary Change on Shirking

Dependent variable: FractionSignedInAbsent ${ }_{i p}$

\begin{tabular}{|c|c|c|c|c|}
\hline & (1) & (2) & (3) & (4) \\
\hline$\Delta$ InSalary $_{c}$ & $\begin{array}{c}-0.0090 \\
(0.0138)\end{array}$ & $\begin{array}{c}-0.0160 \\
(0.0165)\end{array}$ & $\begin{array}{c}-0.0160 \\
(0.0165)\end{array}$ & \\
\hline$E P 7_{p}$ & $\begin{array}{c}0.00286 \\
(0.01335)\end{array}$ & $\begin{array}{c}-0.00081 \\
(0.01377)\end{array}$ & $\begin{array}{c}0.000091 \\
(0.013716)\end{array}$ & $\begin{array}{c}0.00525 \\
(0.00677)\end{array}$ \\
\hline$E P 7_{p} \times \Delta \operatorname{lnSalary}{ }_{c}$ & $\begin{array}{c}0.0253 \\
(0.0168)\end{array}$ & $\begin{array}{c}0.0268 \\
(0.0185)\end{array}$ & $\begin{array}{c}0.0250 \\
(0.0187)\end{array}$ & $\begin{array}{c}-0.00084 \\
(0.01189)\end{array}$ \\
\hline $\ln G D P P C_{c p}$ & & $\begin{array}{c}0.0011 \\
(0.0201)\end{array}$ & $\begin{array}{l}-0.0030 \\
(0.0194)\end{array}$ & $\begin{array}{l}0.2994 * * \\
(0.0991)\end{array}$ \\
\hline Corruption $_{c p}$ & & $\begin{array}{l}0.0202 * \\
(0.0084)\end{array}$ & $\begin{array}{c}0.0189 * \\
(0.0083)\end{array}$ & $\begin{array}{c}-0.0345 \\
(0.0389)\end{array}$ \\
\hline$A g e_{i p}$ & & & $\begin{array}{c}0.00215 \\
(0.00146)\end{array}$ & $\begin{array}{c}0.00175 \\
(0.00147)\end{array}$ \\
\hline$A g e S q_{i p} / 100$ & & & $\begin{array}{c}-0.00159 \\
(0.00138)\end{array}$ & $\begin{array}{c}-0.00129 \\
(0.00142)\end{array}$ \\
\hline lnTenure $_{i p}$ & & & $\begin{array}{c}0.00221 \\
(0.00288)\end{array}$ & $\begin{array}{c}0.00221 \\
(0.00253)\end{array}$ \\
\hline Country Fixed Effects & No & No & No & Yes \\
\hline Observations & 1,410 & 1,410 & 1,410 & 1,410 \\
\hline$R^{2}$ & 0.018 & 0.041 & 0.048 & 0.105 \\
\hline
\end{tabular}

OLS; robust standard errors clustered by country in parentheses. The level of observation is MEP-Parliament for EP6 and EP7. The sample consists of all MEPs in EP6 and EP7. The dependent variable in all regressions is FractionSignedInAbsent $i_{i}$, the fraction of sittings during which MEP $i$ signed the register in the first parliament year of parliament $p$ that she did not participate in any of the roll-call votes. InSalary $_{c}$ is defined as the logarithm of 84,000 (the post-change uniform salary level) minus the logarithm of the salary for MEPs from country $c$ as of December 2004. $E P 7_{p}$ is an indicator variable for whether $p=7$. $\operatorname{lnGDPPC} C_{c p}, \operatorname{Corruption}_{c p}, \mathrm{Age}_{i p}, \mathrm{AgeS}_{i p} / 100$, and InTenure $_{i p}$ are measured in the first year of parliament $p$ and are defined in Table 1.

* significant at 5 percent; ** significant at 1 percent. 
TABLE 9

Effect of Salary Change on the Intensive Margin of Labor Supply

\begin{tabular}{|c|c|c|c|c|}
\hline & (1) & (2) & (3) & (4) \\
\hline Dependent variable: & \multicolumn{2}{|c|}{ FractionAbsent $_{i p}$} & \multicolumn{2}{|c|}{ FractionSignedInAbsent $_{i_{1}}$} \\
\hline & \multicolumn{4}{|c|}{ Panel A: Freshman MEPs } \\
\hline$\Delta$ InSalary $_{c}$ & $\begin{array}{c}-0.0130 \\
(0.0348)\end{array}$ & & $\begin{array}{c}-0.0115 \\
(0.0180)\end{array}$ & \\
\hline$E P 7_{p}$ & $\begin{array}{c}-0.0316 \\
(0.0227)\end{array}$ & $\begin{array}{c}-0.0291 \\
(0.0154)\end{array}$ & $\begin{array}{c}-0.0194 \\
(0.0136)\end{array}$ & $\begin{array}{c}-0.0127 \\
(0.0081)\end{array}$ \\
\hline$E P 7_{p} \times \Delta \operatorname{lnSalary}{ }_{c}$ & $\begin{array}{c}0.0567 \\
(0.0283)\end{array}$ & $\begin{array}{c}0.0127 \\
(0.0224)\end{array}$ & $\begin{array}{c}0.0428 * \\
(0.0188)\end{array}$ & $\begin{array}{c}0.0178 \\
(0.0189)\end{array}$ \\
\hline MEP by EP Controls & Yes & Yes & Yes & Yes \\
\hline Country by EP Controls & Yes & Yes & Yes & Yes \\
\hline Country Fixed Effects & No & Yes & No & Yes \\
\hline Observations & 709 & 709 & 709 & 709 \\
\hline \multirow[t]{2}{*}{$R^{2}$} & 0.058 & 0.112 & 0.063 & 0.120 \\
\hline & \multicolumn{4}{|c|}{ Panel B: Incumbent MEPs } \\
\hline$\Delta$ InSalary $_{c}$ & $\begin{array}{c}-0.0369 \\
(0.0410)\end{array}$ & & $\begin{array}{c}-0.0189 \\
(0.0170)\end{array}$ & \\
\hline$E P 7_{p}$ & $\begin{array}{c}0.0028 \\
(0.0244)\end{array}$ & $\begin{array}{c}0.0180 \\
(0.0140)\end{array}$ & $\begin{array}{c}0.0170 \\
(0.0127)\end{array}$ & $\begin{array}{c}0.0210^{*} \\
(0.0078)\end{array}$ \\
\hline$E P 7_{p} \times \Delta \operatorname{lnSalary}{ }_{c}$ & $\begin{array}{c}0.0215 \\
(0.0357)\end{array}$ & $\begin{array}{c}-0.0067 \\
(0.0284)\end{array}$ & $\begin{array}{c}0.0015 \\
(0.0190)\end{array}$ & $\begin{array}{c}-0.0188 \\
(0.0140)\end{array}$ \\
\hline MEP by EP Controls & Yes & Yes & Yes & Yes \\
\hline Country by EP Controls & Yes & Yes & Yes & Yes \\
\hline Country Fixed Effects & No & Yes & No & Yes \\
\hline Observations & 708 & 708 & 701 & 701 \\
\hline$R^{2}$ & 0.054 & 0.115 & 0.067 & 0.140 \\
\hline
\end{tabular}

OLS; robust standard errors clustered by country in parentheses. The level of observation is MEP-Parliament for EP6 and EP7. The sample consists of all MEPs in EP6 and EP7. FractionAbsent $i p$ is the fraction of sittings in the first parliament year of parliament $p$ during which MEP $i$ did not participate in any of the roll-call votes. FractionSignedInAbsent $i_{i p}$ is the fraction of sittings during which MEP $i$ signed the register in the first parliament year of parliament $p$ that she did not participate in any of the roll-call votes. All columns include Country by EP

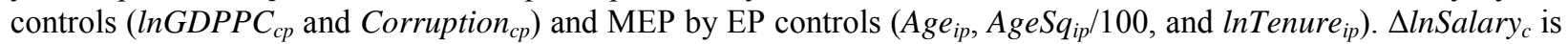
defined as the logarithm of 84,000 (the post-change uniform salary level) minus the logarithm of the salary for MEPs from country $c$ as of December 2004. $E P 7_{p}$ is an indicator variable for whether $p=7$. $\ln G D P P C_{c p}$, Corruption $_{c p}$, Age $_{i p}, \mathrm{AgeSq}_{i p} / 100$, and InTenure $_{i p}$ are measured in the first year of parliament $p$ and are defined in Table 1. * significant at 5 percent; ${ }^{* *}$ significant at 1 percent. 
TABLE 10

Effect of Salary Change on MEP Selection as Measured By College Selectivity Dependent variable: FractionRankedCollege ${ }_{c p}$

\begin{tabular}{|c|c|c|c|c|c|c|}
\hline \multirow[t]{2}{*}{ MEPs Missing College Data: } & \multicolumn{3}{|c|}{ Dropped } & \multicolumn{3}{|c|}{ Coded as Unranked } \\
\hline & (1) & $(2)$ & (3) & (4) & $(5)$ & $(6)$ \\
\hline$\Delta$ InSalary $_{c}$ & $\begin{array}{c}-0.0344 \\
(0.0564)\end{array}$ & $\begin{array}{c}-0.0020 \\
(0.0922)\end{array}$ & & $\begin{array}{c}-0.0164 \\
(0.0507)\end{array}$ & $\begin{array}{c}0.0092 \\
(0.0820)\end{array}$ & \\
\hline$E P 7_{p}$ & $\begin{array}{l}0.1285^{* *} \\
(0.0218)\end{array}$ & $\begin{array}{l}0.1463 * * \\
(0.0299)\end{array}$ & $\begin{array}{c}0.1357 * \\
(0.0624)\end{array}$ & $\begin{array}{l}0.1558 * * \\
(0.0226)\end{array}$ & $\begin{array}{c}0.1744^{* *} \\
(0.0267)\end{array}$ & $\begin{array}{r}0.1605^{*} \\
(0.0690)\end{array}$ \\
\hline$E P 7_{p} \times \Delta$ lnSalary $_{c}$ & $\begin{array}{c}-0.0600 * * \\
(0.0162)\end{array}$ & $\begin{array}{r}-0.0645^{*} \\
(0.0263)\end{array}$ & $\begin{array}{c}-0.0836 \\
(0.0455)\end{array}$ & $\begin{array}{c}-0.0759 * * \\
(0.0150)\end{array}$ & $\begin{array}{l}-0.0794 * * \\
(0.0243)\end{array}$ & $\begin{array}{r}-0.1024 * \\
(0.0441)\end{array}$ \\
\hline $\ln G D P P C_{c p}$ & & $\begin{array}{c}-0.0174 \\
(0.1603)\end{array}$ & $\begin{array}{c}0.1607 \\
(0.3666)\end{array}$ & & $\begin{array}{c}-0.0274 \\
(0.1432)\end{array}$ & $\begin{array}{c}0.1927 \\
(0.3542)\end{array}$ \\
\hline Corruption $_{c p}$ & & $\begin{array}{c}-0.1045 \\
(0.1013)\end{array}$ & $\begin{array}{c}-0.0817 \\
(0.2348)\end{array}$ & & $\begin{array}{c}-0.1064 \\
(0.0878)\end{array}$ & $\begin{array}{c}-0.0744 \\
(0.2468)\end{array}$ \\
\hline Country Fixed Effects & No & No & Yes & No & No & Yes \\
\hline Observations & 50 & 50 & 50 & 50 & 50 & 50 \\
\hline$R^{2}$ & 0.127 & 0.199 & 0.944 & 0.171 & 0.248 & 0.940 \\
\hline
\end{tabular}

OLS; robust standard errors clustered by country in parentheses. The level of observation is Country-Parliament for EP6 and EP7. The dependent variable in all regressions is FractionRankedCollege $e_{c p}$, the fraction of MEPs from country $c$ in parliament $p$ who attended a school ranked in the top 500 by the 2010 Academic Ranking of World Universities. In Columns (1)-(3), MEPs that are missing college information are dropped from the sample. In Columns (4)-(6), MEPs that are missing college information are assumed to not have attended a school ranked in the top 500. $\Delta$ lnSalary $_{c}$ is defined as the logarithm of 84,000 (the post-change uniform salary level) minus the logarithm of the salary for MEPs from country $c$ as of December $2004 . E P 7_{p}$ is an indicator variable for whether $p=7$. $\operatorname{lnGDPPC}_{c p}$ and Corruption $c$ are measured in the last year of parliament $p-1$ and are defined in Table $1 . *$ significant at 5 percent; ** significant at 1 percent. 
TABLE 11

Effect of Absenteeism on Likelihood MEP Is Reelected

Dependent variable: ReElected $_{i p}$

\begin{tabular}{|c|c|c|c|c|c|c|}
\hline & $(1)$ & $(2)$ & (3) & (4) & $(5)$ & $(6)$ \\
\hline FractionAbsent $_{i p-1}$ & $\begin{array}{c}-0.3375^{*} \\
(0.1313)\end{array}$ & $\begin{array}{c}-0.2543^{*} \\
(0.1049)\end{array}$ & & & & \\
\hline FractionSignedIn $_{i p-1}$ & & & $\begin{array}{c}0.3293 * \\
(0.1503)\end{array}$ & $\begin{array}{c}0.2210 \\
(0.1285)\end{array}$ & & \\
\hline FractionSignedInAbsent $_{i p-1}$ & & & & & $\begin{array}{c}-0.4745^{*} \\
(0.2021)\end{array}$ & $\begin{array}{c}-0.3749 * \\
(0.1461)\end{array}$ \\
\hline$E P 7_{p}$ & & $\begin{array}{c}0.0217 \\
(0.0462)\end{array}$ & & $\begin{array}{c}0.0243 \\
(0.0452)\end{array}$ & & $\begin{array}{c}0.0313 \\
(0.0480)\end{array}$ \\
\hline $\ln G D P P C_{c p}$ & & $\begin{array}{c}-1.1719^{*} \\
(0.5379)\end{array}$ & & $\begin{array}{c}-1.1824 * \\
(0.5222)\end{array}$ & & $\begin{array}{c}-1.2744 * \\
(0.5571)\end{array}$ \\
\hline Corruption $_{c p}$ & & $\begin{array}{c}-0.2819 \\
(0.3773)\end{array}$ & & $\begin{array}{c}-0.3036 \\
(0.3667)\end{array}$ & & $\begin{array}{c}-0.2671 \\
(0.3850)\end{array}$ \\
\hline $\operatorname{Age}_{i p}$ & & $\begin{array}{c}0.0060 \\
(0.0149)\end{array}$ & & $\begin{array}{c}0.0073 \\
(0.0151)\end{array}$ & & $\begin{array}{c}0.0091 \\
(0.0150)\end{array}$ \\
\hline$A g e S q_{i p} / 100$ & & $\begin{array}{c}-0.0112 \\
(0.0140)\end{array}$ & & $\begin{array}{c}-0.0124 \\
(0.0142)\end{array}$ & & $\begin{array}{c}-0.0141 \\
(0.0141)\end{array}$ \\
\hline InTenure $_{i p}$ & & $\begin{array}{c}0.1001 * \\
(0.0403) \\
\end{array}$ & & $\begin{array}{c}0.1007 * \\
(0.0415)\end{array}$ & & $\begin{array}{c}0.0946^{*} \\
(0.0396) \\
\end{array}$ \\
\hline Country Fixed Effects & No & Yes & No & Yes & No & Yes \\
\hline Observations & 967 & 967 & 967 & 967 & 965 & 965 \\
\hline$R^{2}$ & 0.017 & 0.130 & 0.013 & 0.126 & 0.010 & 0.128 \\
\hline
\end{tabular}

Linear probability model; robust standard errors clustered by country in parentheses. The level of observation is MEP-Parliament for EP6 and EP7. The sample consists of all MEPs who served in EP5 and ran for reelection for EP6 and all MEPs who served in EP6 and ran for reelection for EP7. The dependent variable in all regressions is ReElected $d_{i p}$, an indicator variable for whether MEP $i$ was reelected to parliament $p . E P 7_{p}$ is an indicator variable for whether $p=7$. InGDPPC $C_{c p}$, Corruption $_{c p}$, Age $_{i p}$, AgeSq $_{i p} / 100$, and lnTenure $i p$ are measured in the last year of parliament $p-1$ and are defined in Table 1. FractionAbsent $i p$ is the fraction of sittings in all years of parliament $p$ during which MEP $i$ did not participate in any of the roll-call votes. FractionSignedIn $n_{i p}$ is the fraction of sittings in all years of parliament $p$ during which MEP $i$ signed the daily register. FractionSignedInAbsent $t_{i p}$ is the fraction of sittings during which MEP $i$ signed the register in all years of parliament $p$ that she did not participate in any of the roll-call votes. * significant at 5 percent; ** significant at 1 percent. 
TABLE 12

The Effect of Salary Change on MEPs' Support of Salary Harmonization Dependent variable: VoteForSalaryChange ${ }_{i}$

\begin{tabular}{lccc}
\hline \hline & $(1)$ & $(2)$ & $(3)$ \\
\hline InSalary $_{c}$ & 0.0016 & -0.0045 & 0.1165 \\
& $(0.0569)$ & $(0.0572)$ & $(0.1217)$ \\
Age $_{i}$ & & 0.0068 & 0.0073 \\
& & $(0.0103)$ & $(0.0098)$ \\
AgeSq$_{i} / 100$ & & -0.0078 & -0.0081 \\
& & $(0.0094)$ & $(0.0089)$ \\
InTenure $_{i}$ & & -0.0081 & -0.0176 \\
& & $(0.0281)$ & $(0.0247)$ \\
InGDPPC $_{C}$ & & & 0.2002 \\
& & & $(0.1909)$ \\
Corruption $_{C}$ & 764 & & 0.0551 \\
& 0.0000 & 0.0016 & $(0.1353)$ \\
\hline Observations $_{R^{2}}$ & & & 764 \\
\hline \hline
\end{tabular}

Linear probability model; robust standard errors clustered by country in parentheses. The level of observation is MEP. The sample consists of all MEPs who were members of the Parliament at the time of the vote. The dependent variable in all regressions is VoteForSalaryChange ${ }_{i}$, an indicator variable for whether MEP $i$ voted for the salary change. $\Delta$ InSalary $_{c}$ is defined as the logarithm of 84,000 (the post-change uniform salary level) minus the logarithm of the salary for MEPs from country $c$ as of December 2004. Age, AgeSq $_{i} / 100$, Tenure $_{i}, \operatorname{lnGDPPC}_{c}$, and Corruption $_{c}$ are measured in the parliament year of the vote on salary change (July 1, 2004 to June 30, 2005) and are defined in Table 1. * significant at 5 percent; ** significant at 1 percent. 